\title{
懸架ばねの腐食耐久性評価法の研究*
}

\author{
尜架ばねの腐食調查委員会

\section{Evaluation Method of Corrosion Fatigue Endurance Properties of Suspension Springs}

\author{
Committee on Corrosion Fatigue Endurance \\ Properties of Suspension Springs
}

\begin{abstract}
There were many evaluation methods of corrosion fatigue endurance properties of suspension springs, depending on spring manufacturers, as many factors affect the properties. Therefore, it has been desired to standardize the evaluation methods. This committee performed theoretical studies as well as experiments on corrosion fatigue. A new evaluation method is recommended on the basis of the experimental results that crack length evaluated from residual fatigue life is a good parameter to compare corrosion fatigue performances of suspension springs relatively.
\end{abstract}

Key words : Suspension spring, Corrosion fatigue endurance properties, Residual fatigue life, Evaluated crack length

\section{1. まえがき}

近年, 高速道路網の拡大, 自動車技術の向上により自動 車の高速走行が可能となった。トラックにおいては, 年間 走行距離の増加, 用途拡大等のため, 使用効率向上の要求 がますます強まってきている。一方, 環境衛生上の問題の ため, 冬期の夕イヤチェンの使用禁止による交通安全上の 見地から，道路に塩をまく対策がとられてきた。そのため， 懸架ばねに関しては塩害による耐久性の低下が重要視され ている。

ばね技術研究会は，これら懸架ばねの諸問題を抽出すべ く, 平成 2 年に「懸架ばねの諸問題に対する調査研究委員 会」を発足させた。2 年間の調査研究の結果, 懸架ばねの 諸問題のなかでは腐食耐久性が重要な課題であり, 試験方 法についてもいくつかあるため, 統一化す心゙きであるとの 意見にまとめられた。そして, 平成 4 年に「懸架ばねの腐 食調査委員会」を発足させ, 将来の統一化に向けて試験方 法を提案することを目的に, 懸架ばねの腐食耐久性の評価 方法を検討することになった。

本報告は懸架ばねの腐食調査委員会の活動の成果内容を まとめたもので，その要点は以下のとおりである。

初めに，懸架ばねメーカで行っている台上腐食耐久試験 方法の現状を調査した。各社では, 各々実車に近い腐食孔 を生成させるという目的で腐食耐久試験を行っており，腐 食条件等を規定する試験方案の統一化は難しいのではない かとの結論に達した。

つぎに市場回収品の調査を行い, 従来から行ってきた残 存耐久試験が, それまでに生じたき裂長さと, 負荷応力に
よって決定されることが認識された。そして，腐食環境下 で生じたき裂長さの大小が，腐食耐久性の評価に利用でき るのではないかとの考えに至った。

そこで新たに，残存寿命から求められるき裂長さによる 腐食耐久性評価の理論的考察を行い，これを裹づける台上 腐食耐久試験を各社で実施した。その結果，残存耐久試験 より求められるき裂長さの大小の比較によって，腐食耐久 性の相対的評価のできることが立証されたので，台上腐食 耐久試験法案の提案を行った。

本委員会の構成は次のとおりである。

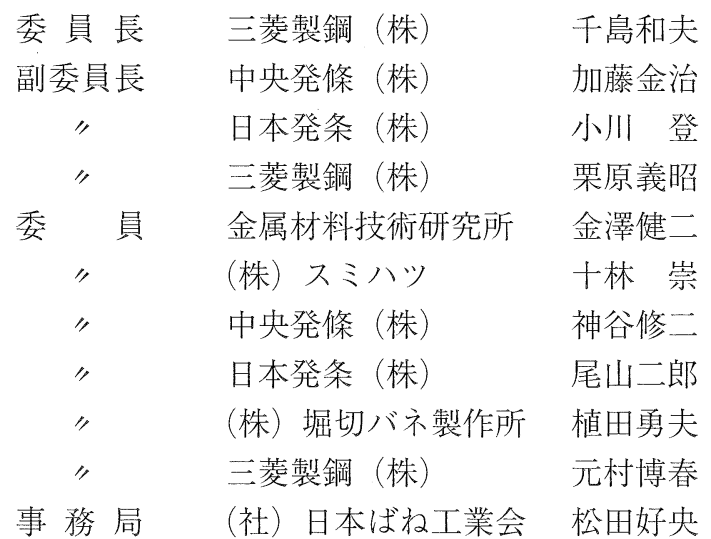

\section{2. 台上腐食耐久試験方法の現状の調査}

\section{1 ばね技術研究会の従来の活動}

ばね論文集における揭載論文等から活動状況を調査した。 その結果を表 1 に示す。

1959年ばね論文集第 6 号の「ばねの疲労に関する共同研 
究」では, 直径 $8 \mathrm{~mm}$ の丸棒に腐食液を滴下しながら回転曲 げ疲労試験を行い，磨きばね鋼の腐食疲労と，腐食疲労に及 ぼすショットピーニングの効果を耐久限度で比較している。

1975年ばね論文集第20号「重ね板ばねの疲れに関する共 同研究」の中では，市場クレームを地域別に集計し，環境 条件の影響を把握するための調査と，実車状態を再現した 静的応力腐食試験や腐食後の疲労試験を行っている。また,
同論文集で中央発條（株）は，「ばね用平鋼の疲れに及ぼす 腐食の影響について」として腐食後の疲労に限定して，塩 水噴霧と屋外暴露による発錆状況の比較を行い，腐食孔の 深さを観察し，これと寿命の関係を定量的に考察している。

1980年ばね論文集第 25 号で日本発条（株）は，「懸架ばね の腐食疲労に関する一考察」として，腐食 $\rightarrow$ 加振 $\rightarrow$ 放置とい うパターンの試験によって，実車走行に招ける腐食疲労状況

表 1 ばね技術研究会の従来の活動

\begin{tabular}{|c|c|c|c|}
\hline 資 料 & ベンチ & 市 場 & カーメ一カ実車 \\
\hline $\begin{array}{l}\text { ばねの疲労に関 } \\
\text { する共同研究 } \\
\text { (1959 ばね論文 } \\
\text { 集6号) }\end{array}$ & 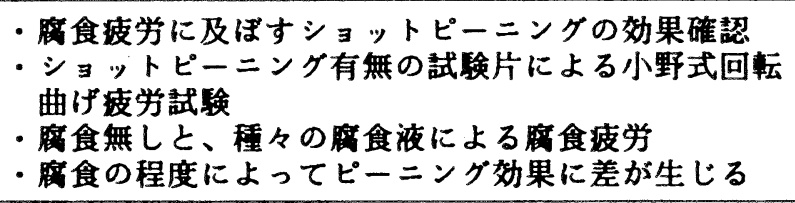 & & \\
\hline $\begin{array}{l}\text { 重ね板ばねの疲 } \\
\text { れに関する共同 } \\
\text { 研究 } \\
(1975 \text { ばね論文 } \\
\text { 集20号) }\end{array}$ & 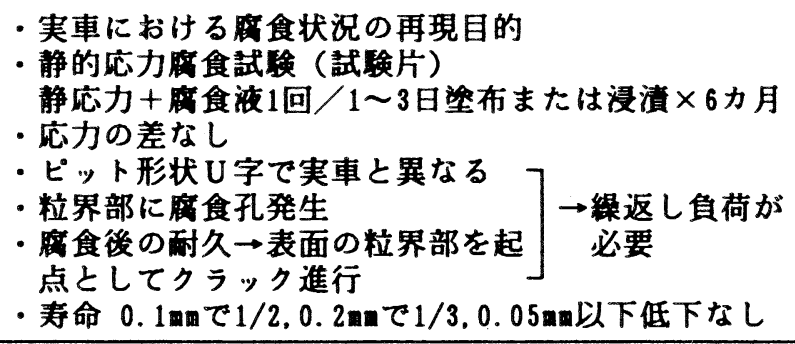 & データ無し & 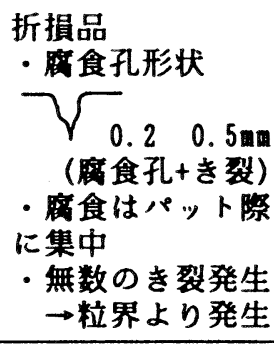 \\
\hline 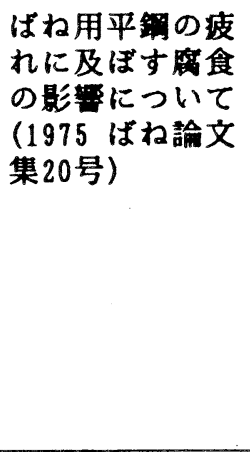 & 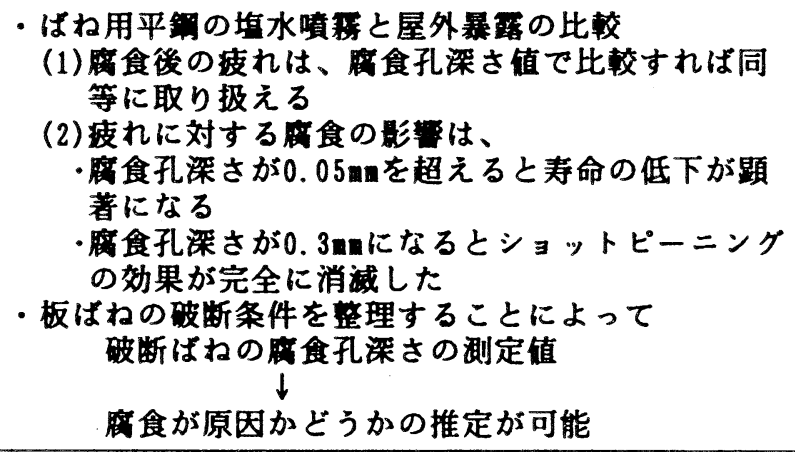 & & \\
\hline $\begin{array}{l}\text { 矁架ばねの席食 } \\
\text { 疲労に関する一 } \\
\text { 考察 } \\
\text { (1980ぱね論文 } \\
\text { 集25号) }\end{array}$ & 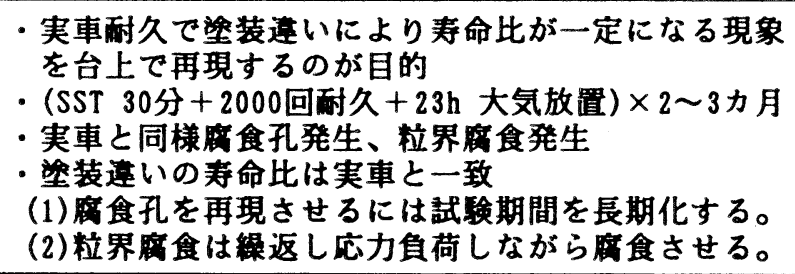 & & 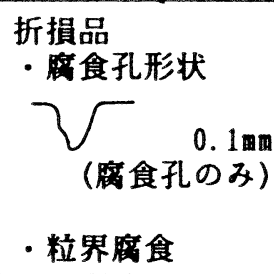 \\
\hline 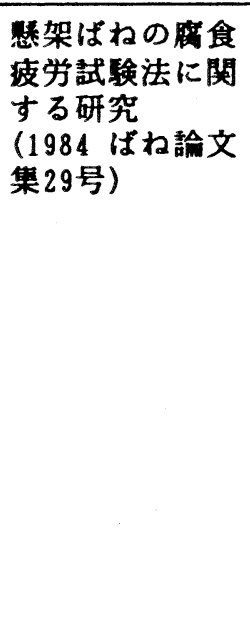 & 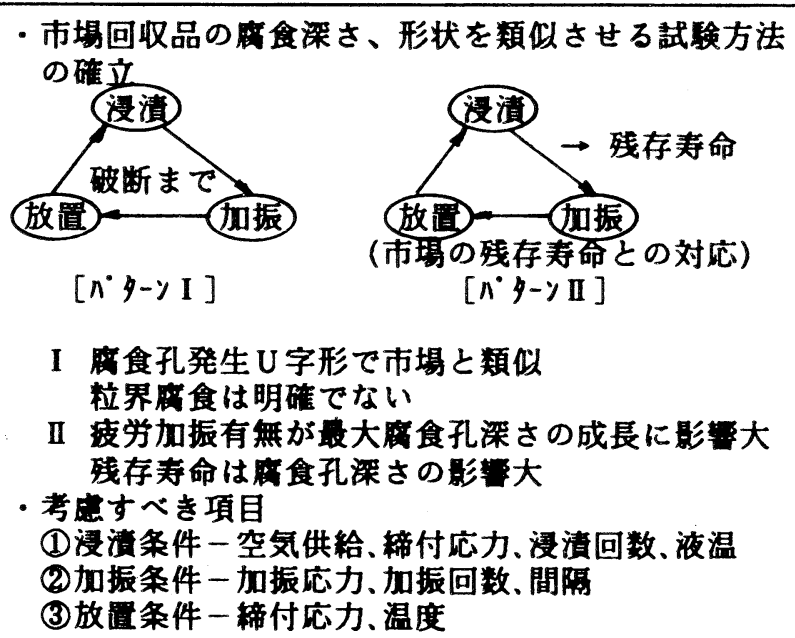 & 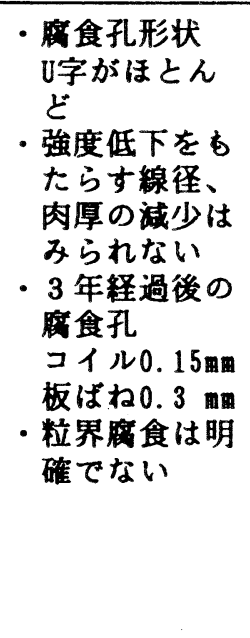 & \\
\hline
\end{tabular}


を台上で再現できることを確認した。しかし，試験期間が長 くなるため，期間を短縮するという検討項目を残した。

1984年ばね論文集第29号では，共同研究「懸架ばねの腐 食疲労試験法に関する研究」にて，自動車用懸架ばねの腐 食耐久試験方法として，市場での腐食状況を台上で再現す る最適な試験条件を見い出すことを目的に，市場回収品の 調査及び台上腐食耐久試験法の検討を行った。そして，自 動車用懸架ばねの市場における腐食状況を定量的に明らか にすること，及び実車の市場における腐食状況がほぼ再現 できる台上腐食耐久試験方法を開発することができた。

\subsection{JASO 自動車部品腐食試験分科会の活動}

分科会はカーメーカ, 部品メーカ, 材料メーカ, 試験機 メーカ, 塗料 (表面処理) メーカ，研究機関のメンバーで 構成され，1987年〜1990年の間，以下の活動を行った。

（1）従来，主流として行われていた塩水噴霧試験による 腐食の試験方法は，市場で発生する腐食との相関性が得ら
れないため，カーメーカ各社がそれぞれ独自の複合サイク ル腐食試験を実施していた。そこで試験方法の統一化を目 標に，市場再現性があり，促進性を有する規格を作成した。

（2）沖縄での 2 年間にわたる屋外暴露で発生した腐食に 対応し, その再現性と促進性の観点から試験方法を制定し, その試験に使用する複合サイクル試験装置（スガ試験機製） を定めた。制定された規格は「JASO M609-91 自動車用 材料腐食試験方法」で，1 サイクル 8 時間を塩水噴霧 2 時 間 $\left(35^{\circ} \mathrm{C} ， 5 \% \mathrm{NaCl}\right)$ ，乾燥 4 時間 $\left(60^{\circ} \mathrm{C} ， 20 \sim 30 \% \mathrm{RH}\right)$ ， 湿潤 2 時間 $\left(50^{\circ} \mathrm{C} ， 95 \% \mathrm{RH}\right)$ とし，サイクル数は当事者間 の協議で定めるというものである。

2.3 各社の台上腐食耐久試験方法の現状及び結果

板ばね及びコイルばねの各社における腐食耐久試験方法 を表 2 , 表 3 に, 試験結果を表 4 に示す。各社の腐食 耐久試験方法は次のとおりである。

（1）板ばねの腐食耐久試験方法について

表 2 ばねメーカー各社に抢ける懸架ばねの腐食耐久試験方法（板ばね）

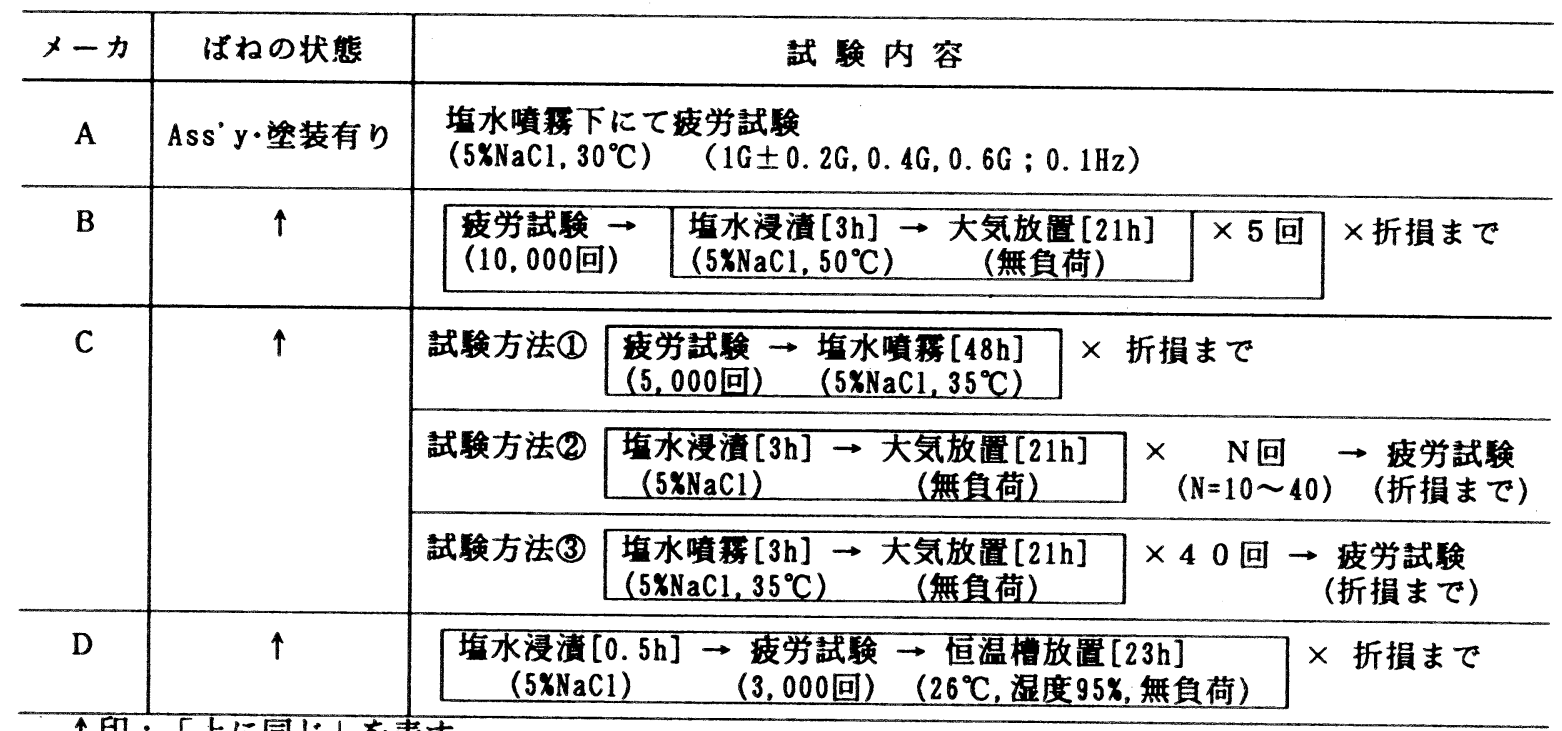

†印：「上に同し」を表す。

表 3 ばねメーカー各社における懸架ばねの腐食耐久試験方法（コイルばね）

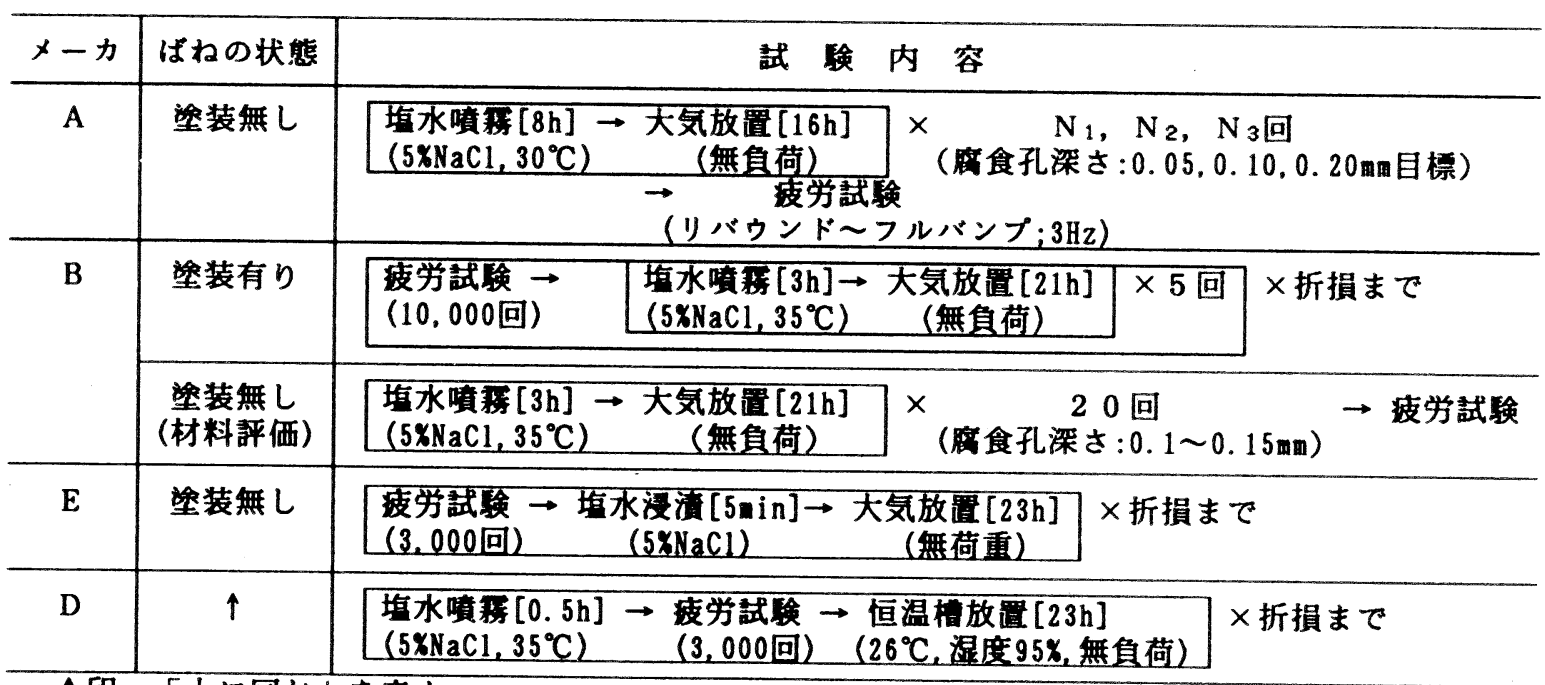

个印：「上に同し」を表す。 


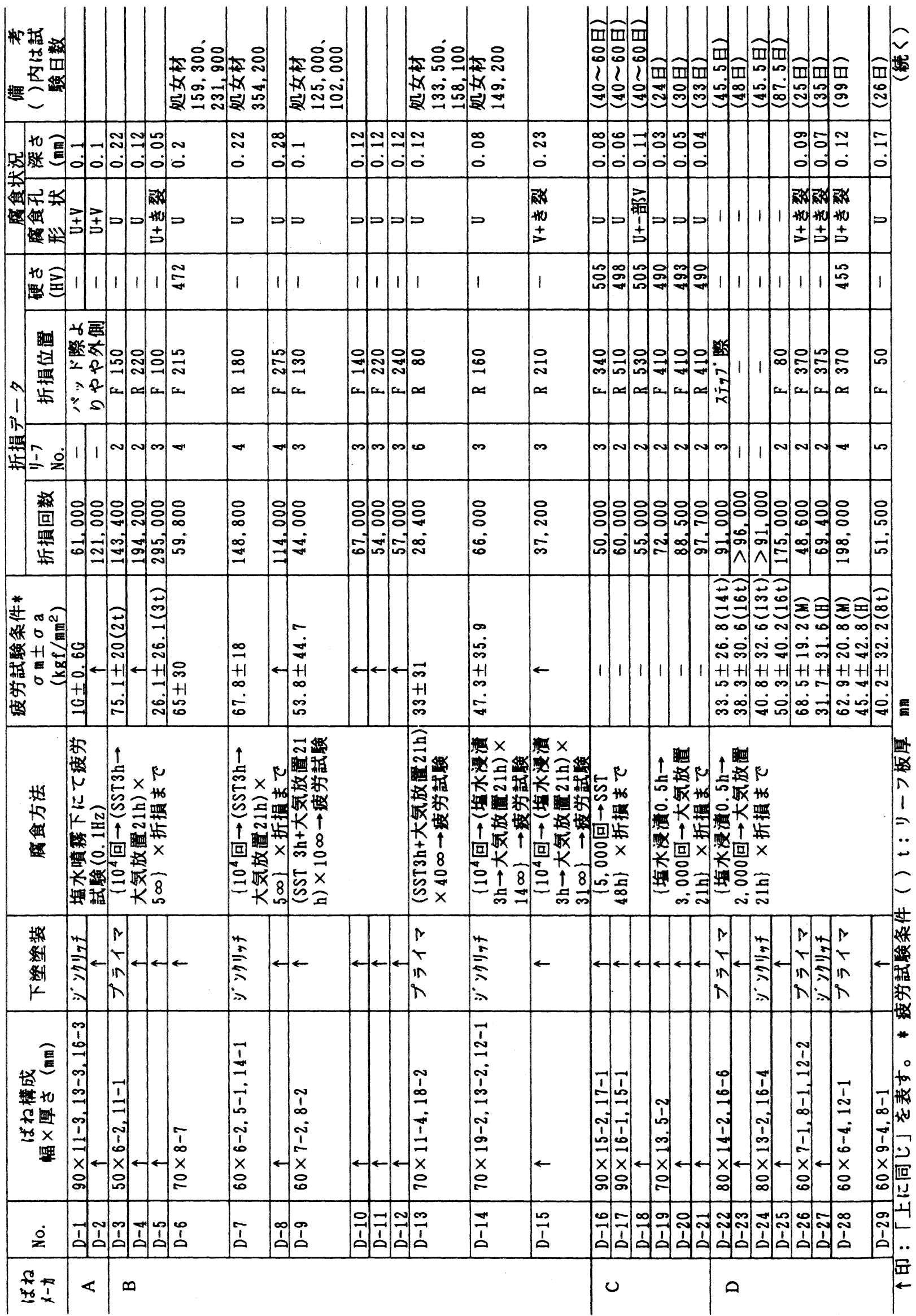




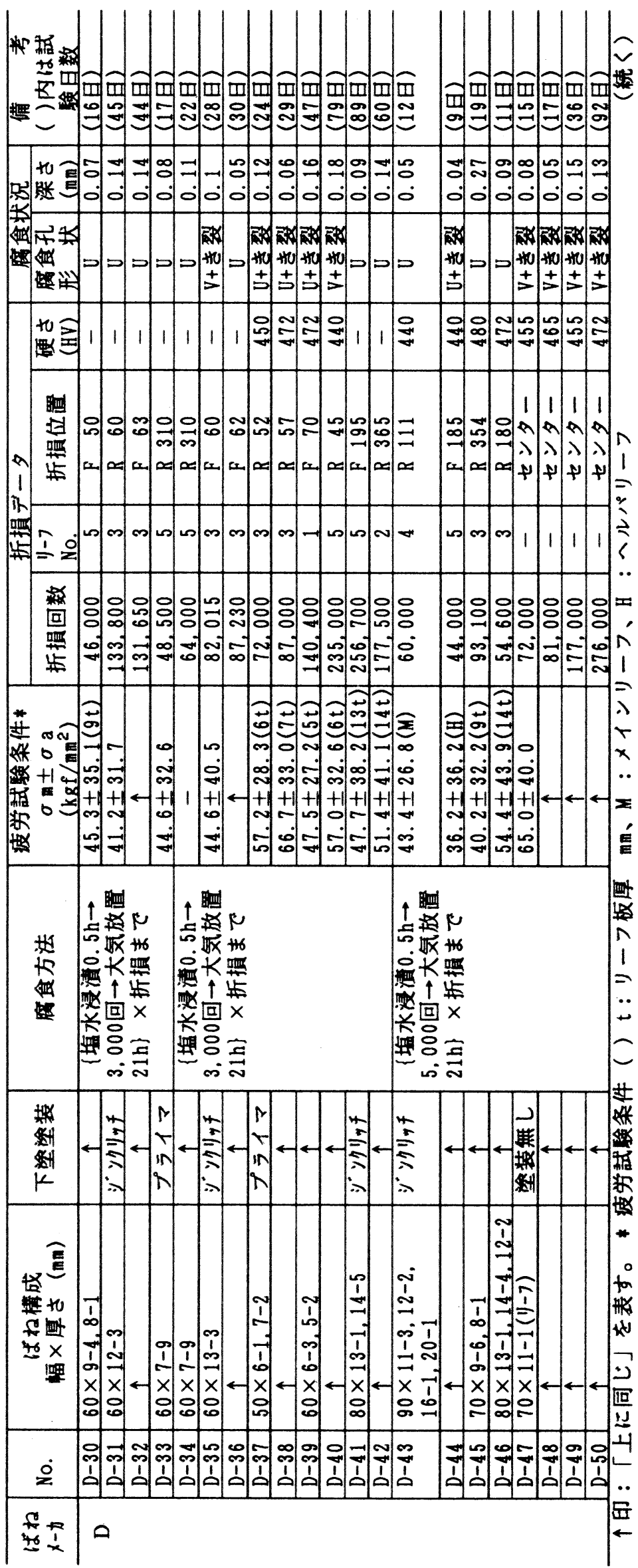
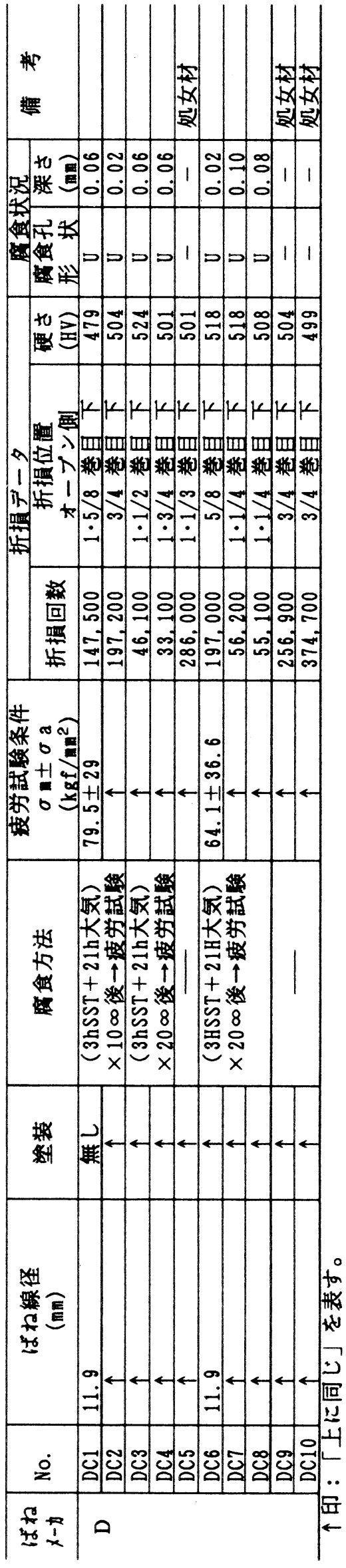
$\mathrm{A}$ 社では塩水噴霧下での疲労試験を実施している。この 方法は，き裂の伝ぱ過程に打いても腐食の影響を与えるこ とが可能である。また，ばねを一度試験機に取付ければ, 折損するまで連続して試験できるので，作業工数の削減を 図ることができる。ただ, 疲労試験機に塩水噴霧装置を 直結させる必要があり, 設備上の制約が大きい。

$\mathrm{B}$ 社では疲労試験と腐食試験の組合わせで実施している。 腐食は塩水浸漬 3 時間後に大気放置 21 時間の 24 時間を 1 サ イクルとし，5サイクルごとに疲労試験を 10,000 回行い， 折損まで繰返す。設備は通常の疲労試験機と塩水槽があれ ばよいが，1日に 1 回，試験片を塩水槽から出し入れし， 5 日ごとに疲労試験を実施する必要がある。

$\mathrm{C}$ 社は 3 種類の試験方法を採用している。試験方法(1)は $\mathrm{B}$ 社と同じく, 疲労試験と腐食試験の組合わせである。疲 労試験を 5,000 回と塩水噴霧 48 時間を 1 サイクルとして折 損までこれを繰返す。疲労試験機と塩水噴霧試験機が必要 である。2 日に 1 回, 試験片を塩水噴霧試験機より取出し, 疲労試験を実施する。また, 試験方法(2)(3)は腐食後の疲労 試験である。(2)は塩水浸漬 3 時間，(3)は塩水噴霧 3 時間後 にそれぞれ大気放置21時間の 24 時間を 1 サイクルとし，10 $\sim 40$ 回繰返し，その後疲労試験を行う。

$\mathrm{D}$ 社も疲労試験と腐食試験の組合わせである。塩水浸漬 0.5 時間後に疲労試験を 3,000 回行い, その後恒温槽内で一 定温度・湿度にて 23 時間放置する。24時間を 1 サイクルと して折損まで繰返す。1日 1 回, 試験片の塩水槽, 恒温槽 からの出し入れと疲労試験が必要である。恒温槽放置のた め，ばねの大きさと数量に制約を受ける。

(2) コイルばねの腐食耐久試験方法について

$\mathrm{A}$ 社は未塗装のば数に対して, 腐食後に疲労試験を行っ ている。塩水噴霧 8 時間後に大気放置16時間の 24 時間を 1 サイクルとして，腐食孔深さが $0.05 \sim 0.20 \mathrm{~mm}$ となること を目標とするサイクル数 $N_{I} \sim N_{3}$ 回の後に疲労試験を行う。

$\mathrm{B}$ 社は塗装したばねに対して，板ばねと同様に疲労試験 と腐食試験を組合わせて実施している。腐食は塩水噴霧 3 時間後に大気放置21時間の 24 時間を 1 サイクルとし，5サ イクルごとに疲労試験を 10,000 回行い, これを折損まで繰 返す。また，材料評価として，未塗装のばねに対して，A 社とほほ同様の条件で腐食後に疲労試験を行っている。た だし，塩水噴霧 3 時間後に大気放置 21 時間を 1 サイクルと して，20サイクルの後に疲労試験を行う。

$\mathrm{E}$ 社は未塗装のばねに対して, 疲労試験と腐食試験を組 合わせて実施している。疲労試験 3,000 回後に, 塩水浸漬 を 5 分間行い，その後 23 時間大気放置し，この 24 時間を 1 サイクルとして折損まで繰返す。

$\mathrm{D}$ 社も未塗装のばねに対して, 疲労試験と腐食試験の組 合わせで実施している。塩水噴霧 0.5 時間後に疲労試験を 3,000 回行い, その後恒温槽内で一定温度・湿度にて23時間 放置する。24時間を1サイクルとして折損まで繰返す。板 ばねと同様に，恒温槽放置のため，ばねの大きさと数量に 制約を受ける。

\section{4 調査のまとめ}

各社の試験方法は, ばね論文集で発表されている試験方 法をべースに，それぞれ実車に近い腐食孔を生成させる目 的で腐食耐久試験を行っている。腐食耐久試験の方法には, 腐食試験と疲労試験の両方を実施する方法と, 腐食孔の切

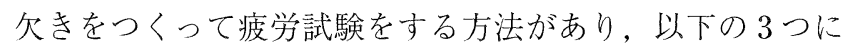
大別される。

(1) 腐食後の疲労試験

（2）腐食十疲労のサイクル試験

(3) 腐食下の連続疲労試験

試験期間は一部10日前後のものもあるが，大半は，30日 ～60日という期間を要している。しかも実車寿命と台上寿 命の相関を求めようとしているが，なかなか良い方法はな い上うである。また，腐食無しの台上耐久との比較試験を 行い, 繰返し数比で評価しているメーカもある。図 1 に示 すように，腐食による損傷で繰返し数は $1 / 10 \sim 1 / 3$ に低下 する場合もある。

カーメーカは，ばねには塗装・材料・設計の総合的な評価 を望んでおり，腐食耐久試験も塗装したばねで行っている。 統一された試験方法としては「JASO M609-91 自動車用 材料腐食試験方法」が制定されたが，カーメーカ各社が従 来行っていた複合サイクル腐食試験との相関がとれないた め，まだ普及していない。

\section{3. 市場回収品, 実車耐久回収品の調查}

\section{1 調查方法}

1978年から1992年にわたり，ばねメーカ各社が保有して いた市場及び実車耐久試験回収品に扔いて, 腐食が原因で 折損した重敉板ばねのデー夕を対象に, ばね仕様, 走行地 域, 走行距離, 折損部位, 腐食状況などを調查した。

\section{2 調査結果}

\subsection{1 市場回収品の調查結果}

調査結果を表 5 に示す。

(1) 調査品の車種, 使用状況調查品の車種は小型バ ン, トラックから中型バス, 大型トラックと幅広く, 走行

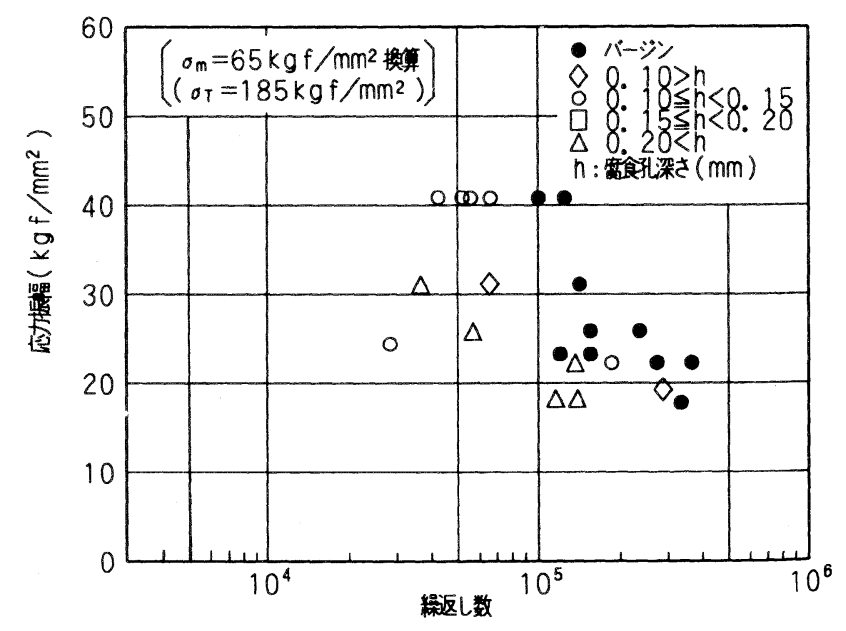

図 1 重社板ばねの腐食状況と耐久性 


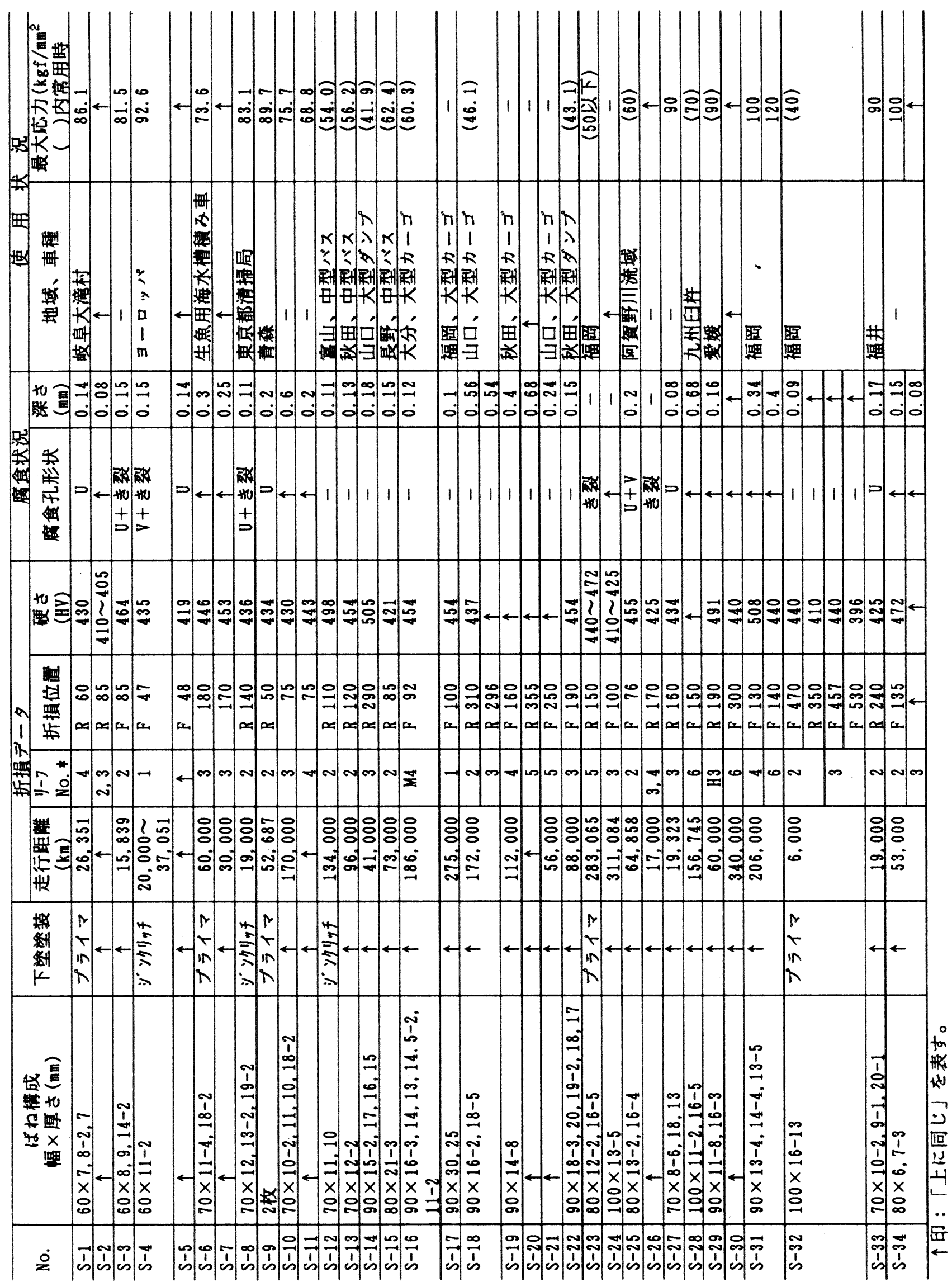


地域は国内の東北，北陸，北九州が大部分で，気象条件等の 地域性が認められる。また一部ヨーロッパが含まれている。 走行距離は $0.6 \sim 34$ 万 $\mathrm{km}$ であった。

（2）腐食孔 図 2 に錆除去後の表面外観写真を示す。 表面には多数の腐食孔が認められ，さらに腐食孔を起点と した疲労き裂がいくつか観察される。図 3 に折損部近傍の 腐食孔の断面写真を示す。腐食孔の断面形状は U 型, V 型 さらに腐食孔底を起点としたき裂の発生等, 種々の形状が 認められる。

図 4 に走行距離と腐食孔深さとの関係を示す。下塗り塗 装にプライマとジンクリッチがある。ジンクリッチ塗装で, センタ穴より $150 \mathrm{~mm}$ 未満の中心部折損品の腐食孔哚さは, 走行距離に関係なくほほ $0.15 \mathrm{~mm}$ であるのに対して，有効 部折損品の腐食孔深さは，10万 $\mathrm{km}$ 以上走行したもので急 激に深くなっている。これは，有効部折損は飛び石，砂の 噛みこみ等によりスポット的に塗膜が剥離し，腐食が内部 に進み，応力も中央部に比べて比較的低いため，腐食孔が かなり深くなってから折損に至るためと考えられる。それ に対し中央部折損は，フレッティング等により塗膜が面剥 離し, 腐食孔も全面に発生し, 応力も高いため腐食孔深さ が $0.15 \mathrm{~mm}$ 程度になると折損に至ってしまうと考えられる。 プライマ塗装品の腐食孔深さは, 折損部位に関係なく, 走 行距離が長くなると深くなる傾向がみられる。

また図 4 に，ばね論文集第29号の「眯架ばねの腐食疲労 試験法に関する共同研究」での調査結果（1979年～1980年 回収品）をプロットしてある。国内走行品は今回調査のプ ライマ塗装品とほぼ同等の傾向である。一方，北米走行品 は，10万 $\mathrm{km}$ 以下の走行では走行地域の腐食環境が厳しい ため, 今回の調查品に比心゙腐食孔深さが深い。しかし10万 $\mathrm{km}$ 以上の走行品では逆に今回調査品の腐食孔深さの方が梁 い傾问がみられる。

\subsection{2 実車耐久回収品の調查結果}

調查結果を表 6 に示す。

(1) 調査品の車種, 走行距離調查品の車種はほとん どが小型バン，トラックであり，一部大型が含まれる。走

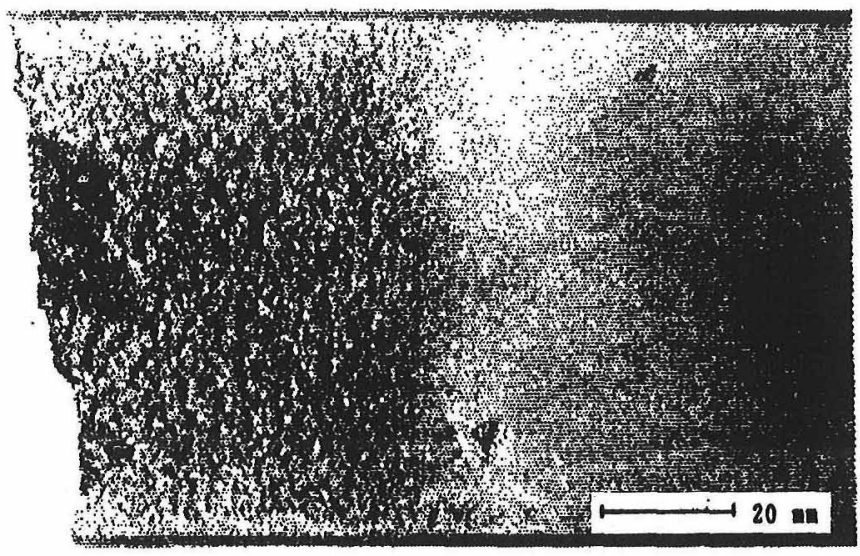

図 2 錆除去後の表面外観写真
行距離は 1 万 $\mathrm{km}$ 前後が最も多く, 20 万 $\mathrm{km}$ のデータも一部 みられる。

（2）腐食孔 腐食孔深さは大半が $0.15 \mathrm{~mm}$ 以下で，大 半が $0.1 \mathrm{~mm}$ 以上であった市場回収品の場合に比べ浅い。図 5 に折損部近傍の腐食孔の断面写真を示すが，腐食孔の断

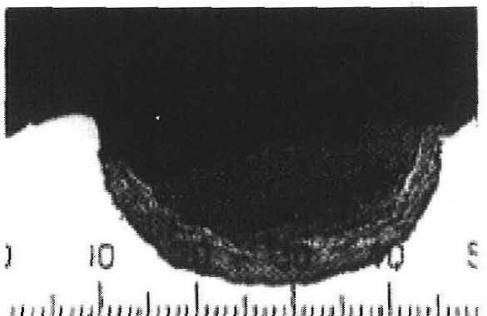

（1）简食孔状況 (No.S-33)（100倍の写真に最小メモリ1mmのス ケールを添えた写真)

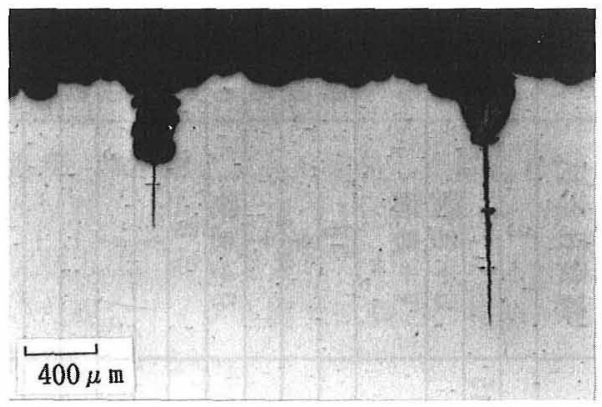

（2）腐食孔状況 (No.S-19)

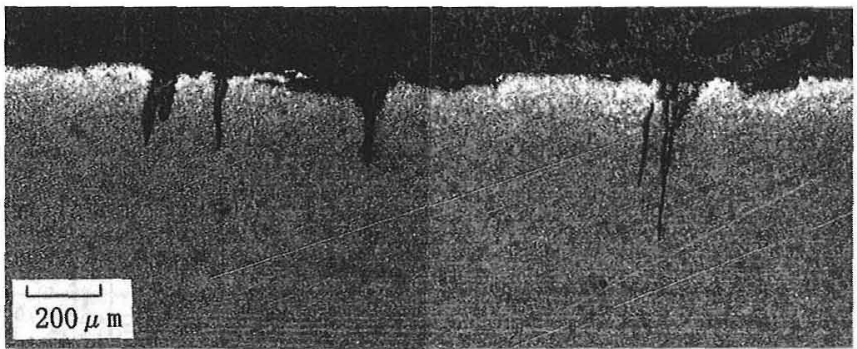

（3）腐食孔状況 (No. S-4)

図 3 市場回収重ね板ばねの折損部近傍の腐食孔の断面写真

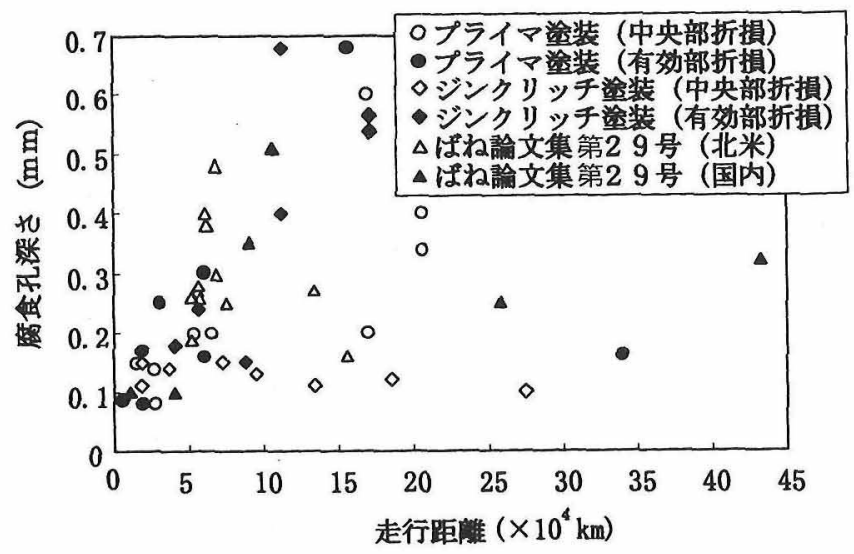

図 4 走行距離と腐食孔深さとの関係 


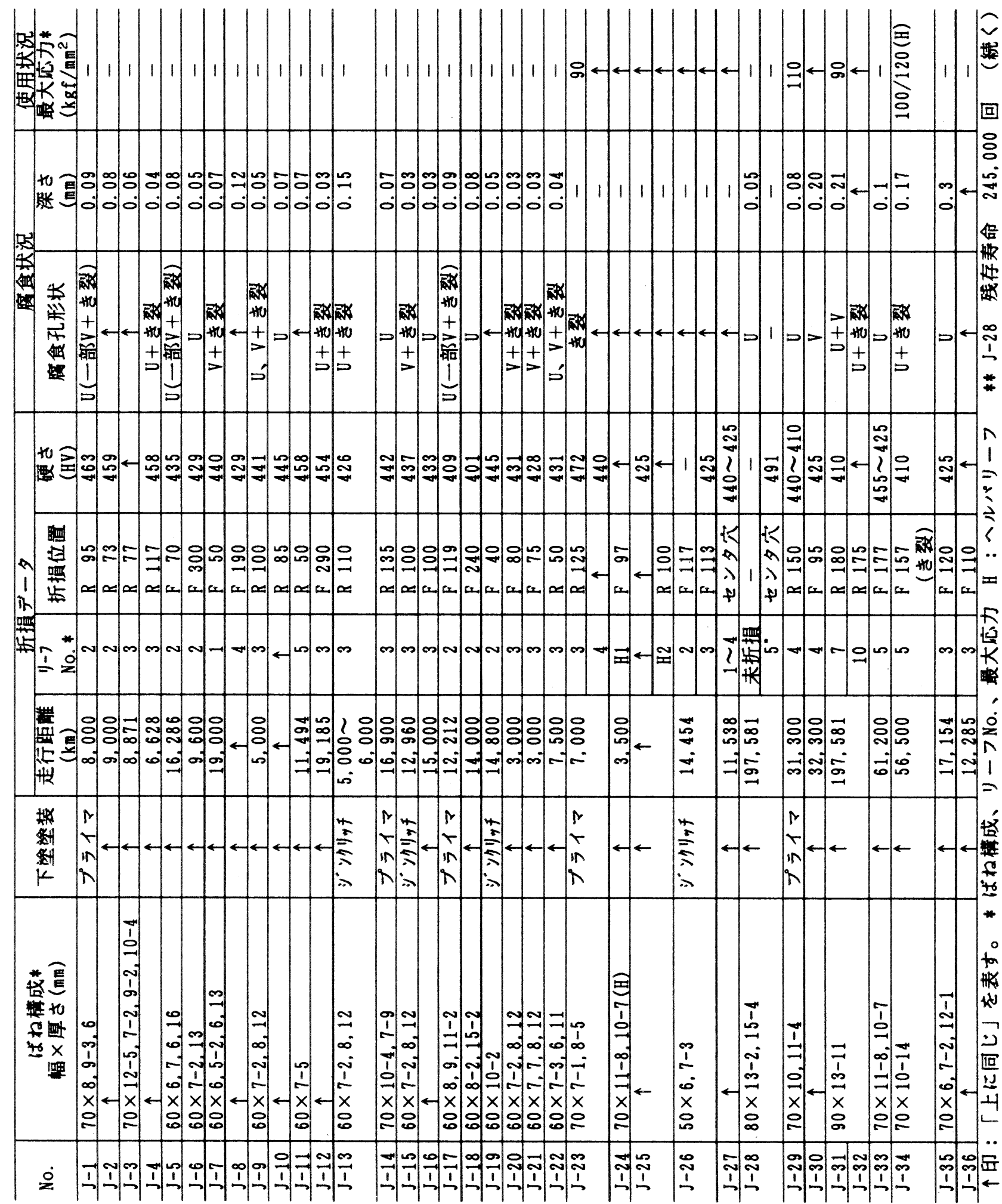




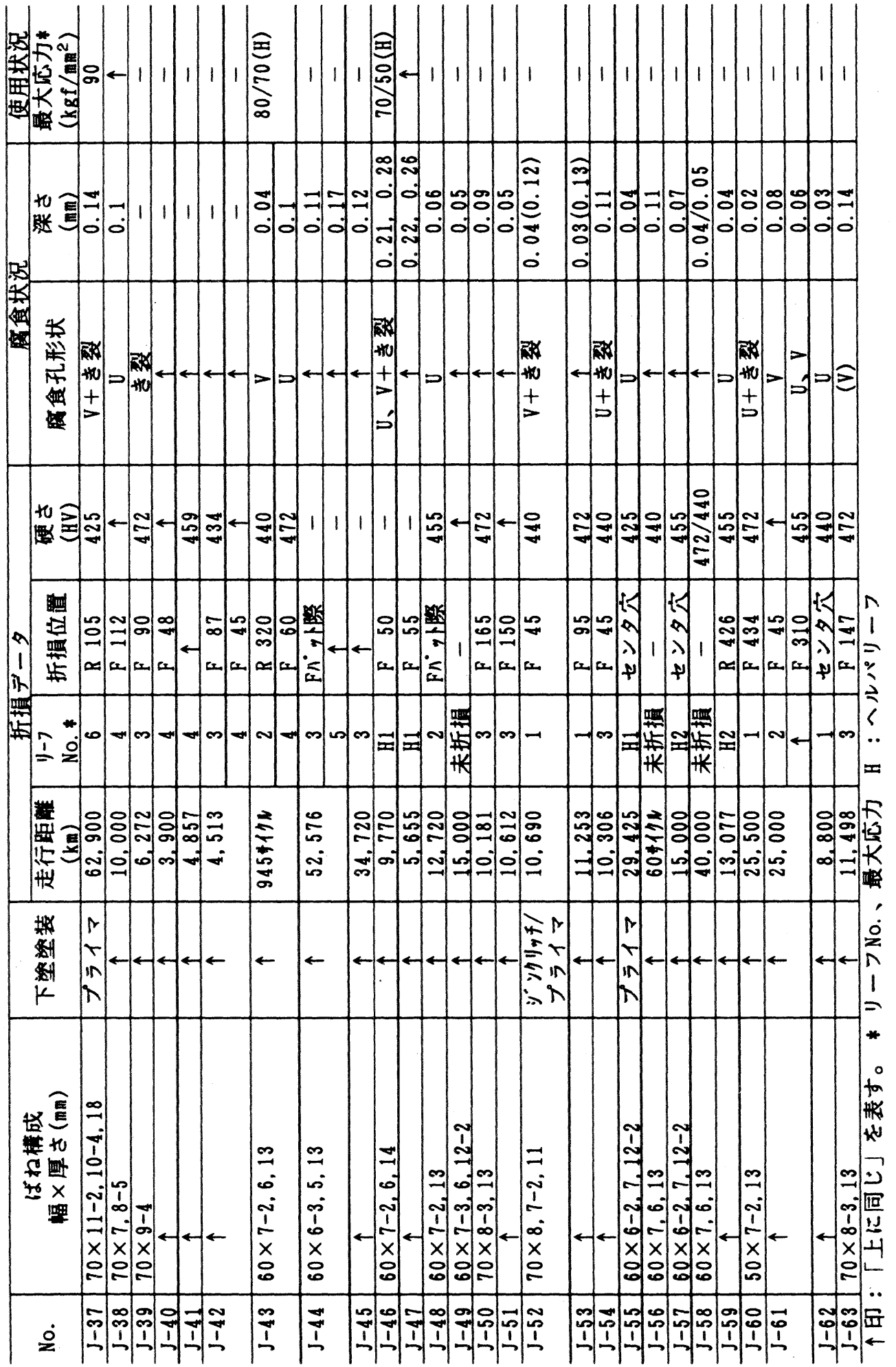


面形状は市場回収品と同様にU 型腐食孔，V 型腐食孔さら に腐食孔底を起点としたき裂の発生等種々の形状が認めら れる。実車耐久試験は加速試験のため, 走行時の応力条件 が厳しく，市場回収品に比べて腐食孔深さが浅いにもかか わらず，き裂の発生が多くみられる。図 6 に走行距離と腐 食孔深さとの関係を示す。走行距離が 1 万 $\mathrm{km}$ 付近に集中 しており，また実車耐久試験条件は個々に異なるため，明 確な相関は認められない。

\section{3 市場一実車耐久試験一台上耐久試験の比較}

（1）折損リーフ，折損部位 市場，実車耐久試験での

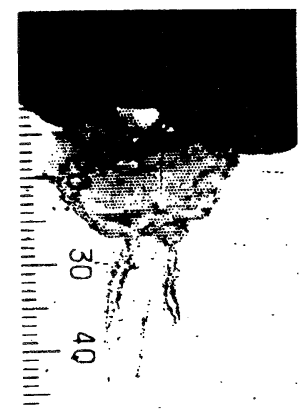

（1）腐食孔状況 (No.J-38)

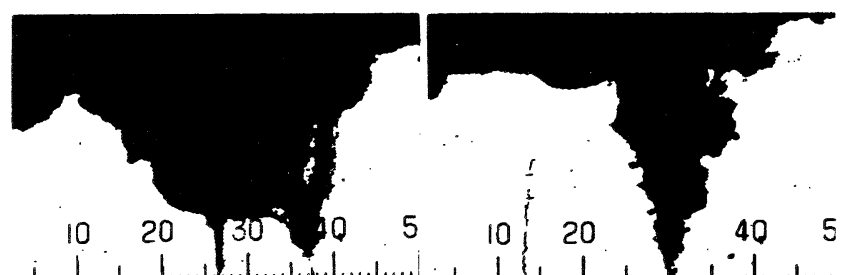

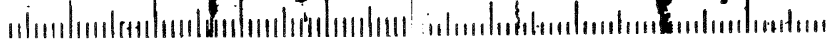

（2）腐食孔状況 (No. J-47)

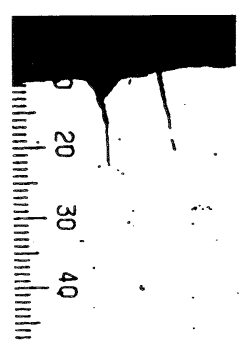

（3）腐食孔状況 (No. J-52)

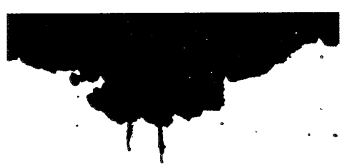

) $10^{\circ} 20: 30 \quad 40$

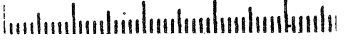

（4）腐食孔状況 (No. J-54)

図 5 実車耐久回収重社板ばねの折損部近傍の腐食孔の断面写真

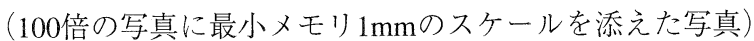

折損リーフNo.，折損位置の頻度分布を図 7, 図 8 に示す。 折損リーフは市場, 実車共にNo. 2, No. 3 リーフが最も多 く，両方で50\%を占める。折損部位は，市場ではセン夕穴 から $50 \mathrm{~mm}$ 以上の部位で全般にわたって折損しているが， 実車耐久試験ではセンタ穴から 50～150mm のクランプ部 近傍の折損が多い。これは，実車耐久試験では腐食の進行 に対し, 疲労の加速の方が大きいため, 発生応力の高いク ランプ近傍の折損が多いと考えられる。

(2) 腐食孔形状各社から提出されたデータより, 市 場での腐食孔の深さと幅の関係をプロットすると, 図 9 の

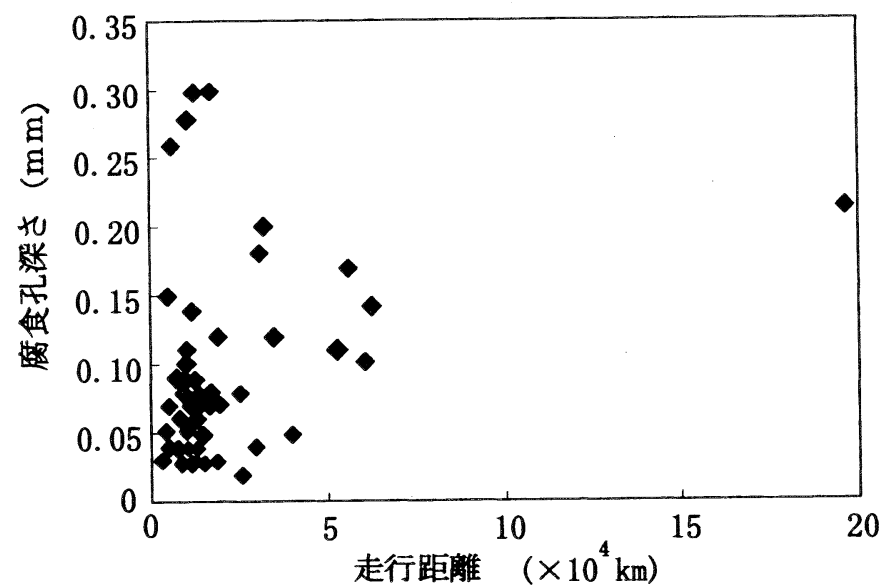

図 6 実車耐久走行距離と腐食孔深さとの関係

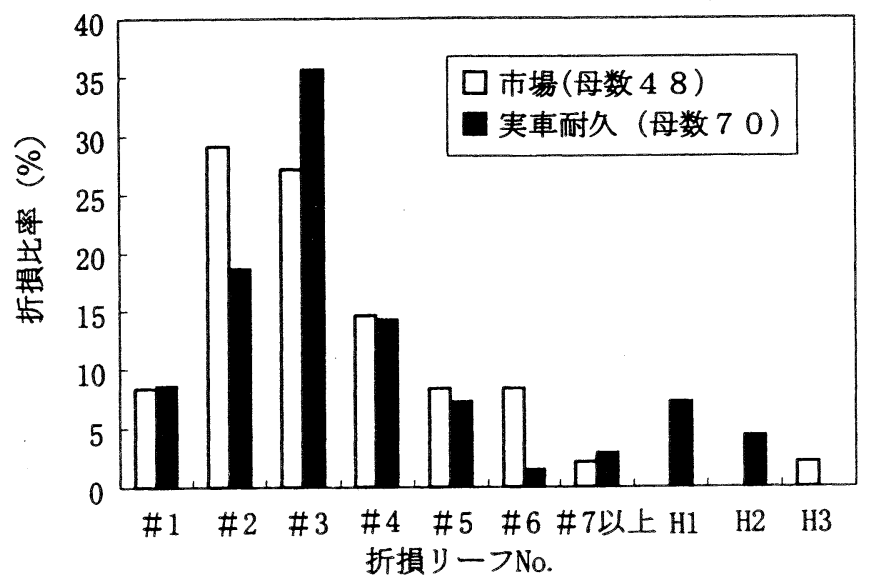

図 7 折損リーフNo.の頻度分布

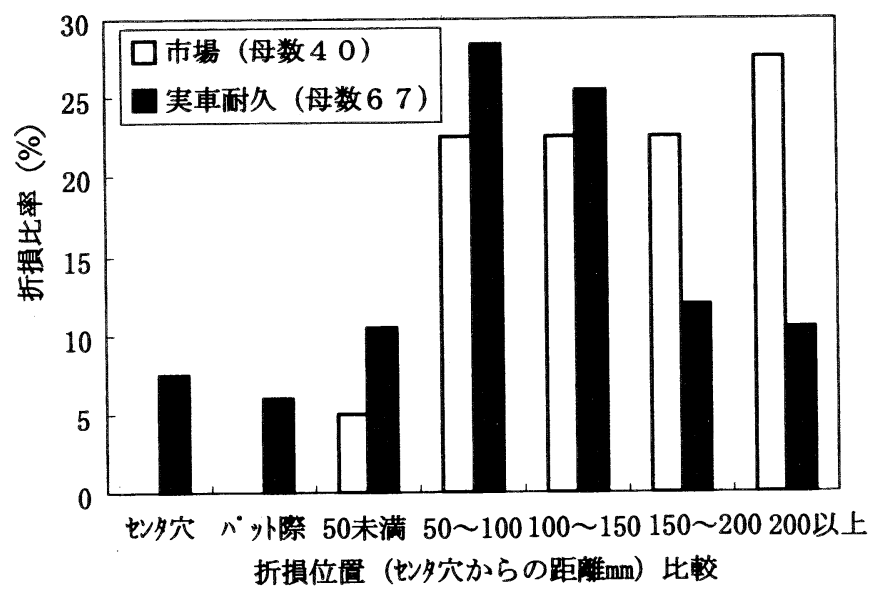

図 8 折損部位（セン夕穴からの距離 $\mathrm{mm}$ ) の頻度分布 


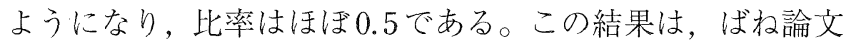
集第29号で述べられている ${ }^{1)}$ 腐食孔の幅と深さの関係と一 致している。

・部のデータより，市場，実車耐久，台上耐久の損傷負 荷形態と $U$ 型腐食孔， $\mathrm{V}$ 型腐食孔，き裂の有無などの腐食 孔形状の関係として，

(a) 市場未折損品の腐食孔形状はU 型になっている。

（b）市場折損品，台上耐久（腐食十酎久のサイクル試験） 折損品では $\mathrm{V}$ 型または $\mathrm{V}$ 型腐食孔からのき裂発生が多く見 られる。

（c）市場で発生したき裂は閉口しているが，台上耐久で は開口している。

等の特徴が見受けられた。しかし，各社から提出された腐 食孔形状デー夕を確認した結果からは一概にはいえないよ うである。すなわち，市場，実車耐久試験，台上耐久試験 ともに腐食孔形状としては，比率は異なるものの， U 型， V 型および腐食孔十き裂がみられる。

したがって，腐食孔形状の $\mathrm{U}$ 型， $\mathrm{V}$ 型，腐食孔十き裂は 腐食疲労過程のある時点の様相を見たものであり，それは 腐食速度とき裂の伝ぱ速度の絡みにより時々刻々変化し, 一義的に決まるものではないと考えられる。すなわち，き 裂伝ぱ速度が腐食速度より小さければ図 3（1）のように腐 食孔のみが成長し，腐食孔が限界寸法を超えてき裂が発生 しても，腐食の進行とき裂伝ぱ速度の絡みにより図 3（2） のようにき裂のみが成長したり，図 3 （3）のようにき裂部 が腐食されたりすると考えられる。

（3）実車耐久試験，台上耐久試験後の残存寿命の比較

ばね論文集で発表されている台上腐食耐久試験法 ${ }^{1)}$, 2) は, 市場回収品の腐食孔深さ, 形状を類似させることを目的と していたが, 腐食孔の発生, 成長過程は腐食速度とき裂伝 ぱ速度の絡みにより非常に複雑であり，それを台上で加速 再現させることは難しいと考えられる。

図 10 は，コイルばねの実車耐久後の残存寿命と台上腐 食耐久後の残存寿命を比較したものである。実車塩害耐久

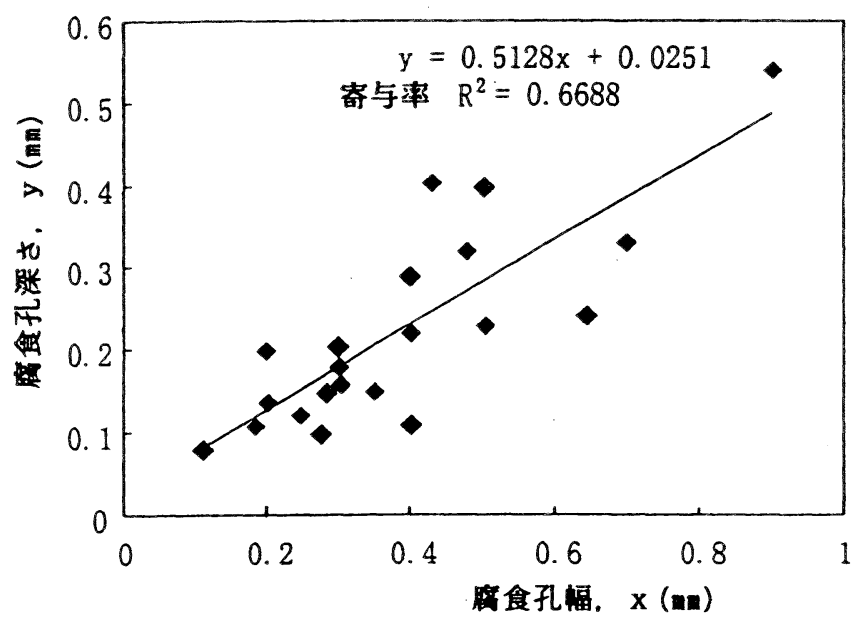

図 9 市場での腐食孔の幅と深さとの関係
の残存寿命が 2 万万回であるのに対し，台上腐食耐久 20 サイクルでの寿命は 4 - 5万回である。ここで，台上耐久 で30サイクル程度に腐食サイクルを増やし，残存寿命が 2 〜3万回になれば，実車塩害耐久と同等の損傷状態になっ ているのではないかと考えられる。すなわち，市場あるい は実車耐久回収品の残存寿命と，台上にて腐食耐久試験を 実施し, 中途で打切った後, 回収品と同一応力条件にて大 気中で求めた残存寿命とが同寿命であれば，台上の損傷状 態が市場あるいは実車耐久と同等であると判断できるもの と考えられる。な捂ここで，残存寿命から評価できる損傷 状態とは，残存耐久試験を開始する時点ですでに形成され ているき裂の長さを意味している。

このように，大気中での残存耐久試験による残存寿命は， それまでに受けた力学条件, 腐食条件によって生じたき裂 を意味する損傷状態を反映したものであるということは， 逆に残存寿命はばねの腐食耐久性を評価する手がかりとな ることを示唆している。

\section{4 まとめ}

市場及び実車耐久試験回収品で，腐食が原因で折損した 重ね板ばねの腐食状況は，U 型，V型抢よび腐食孔十き裂 の形態に分類された。これらは腐食疲労過程のある時点の 様相を見たものであり，それは腐食速度とき裂の伝ぱ速度 の絡みにより時々刻々変化し，一義的に決まるものではな いと考えられた。

大気中での残存耐久試験による残存寿命は，それまでに 受けた力学条件, 腐食条件によって生じたき裂を意味する 損傷状態を反映して抢り，残存寿命はばねの腐食耐久性を 評価する手がかりとなることが示唆された。

\section{4. 腐食耐久性の評価法の検討}

\section{1 腐食耐久性評価の新しい考え方}

これまで，損傷状態として市場，実車に近い腐食孔を生 成させる目的で腐食耐久試験が行われてきたが，市場にお ける腐食条件や力学条件はさまざまであり，それらの状況

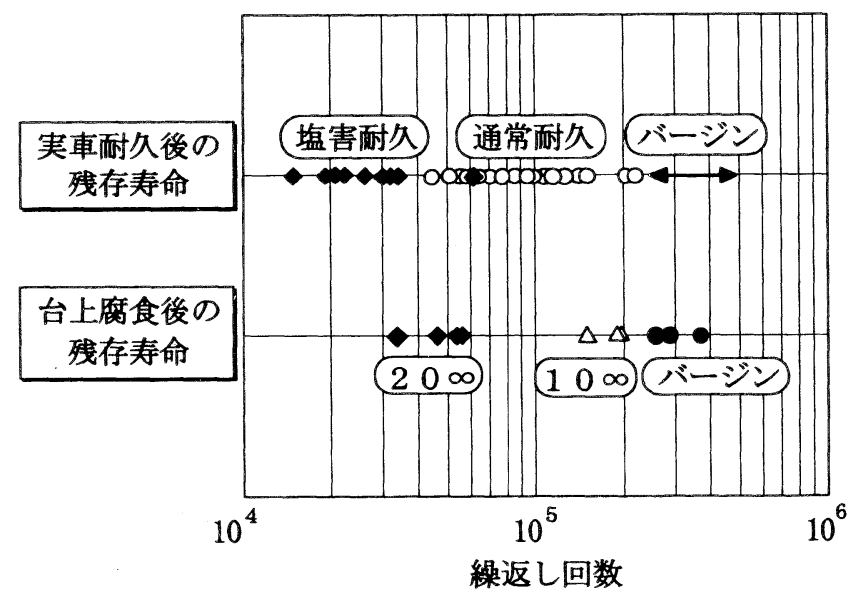

図 10 コイルばねの実車耐久後の残存寿命と台上腐食後の 残存寿命の比較 
を台上で加速再現させることは非常に難しい。これは図 11 に示すように，ばねの腐食耐久特性を左右する要因が多岐 にわたるためである。

したがって, 腐食条件, 力学条件を特定し, ばねの耐久 性を比較しても, 個々に現実に問題となる腐食条件, 力学 条件下でのばねの耐久性の評価にはならない可能性が大で ある。むしろ, 腐食条件, 力学条件の設定は個々の問題に 委䄈るべき性格のものであるといえる。しかし，そのよう な中にあっても, 耐久性の評価に関する何らかの共通の認 識が必要となる。

そこで，ばねの腐食耐久性を調べる方法として，図 12 に示すように，ある程度の腐食条件・力学条件のもとでの 試験を実施した後, 大気中で破壊までの残存耐久試験を行 い，その結果である残存寿命より，既に存在していたき裂 の長さを評価し, そのき裂長さの大小により腐食耐久性を 評価する方法を検討した。

鉄鋼材料の疲労破壊過程は一般に図 13 にも見られるよ うに，(a)き裂の発生過程，（b）発生したき裂が後述する パリス則にしたがって安定して伝ぱする過程，(c) ある時 点から急激に成長して最終破断に至る過程，に大別される。 各過程の疲労寿命に占める割合は，(c) の過程はほほ無視 できるが，(a) と（b）の過程のいずれが支配的かは，対象 物の形状や, 対象物のおかれる環境によって異なる。なお, このような疲労過程のうち, (b) のき裂伝ぱ過程の占める 寿命は, (b) の過程開始時点のき裂長さ $\mathrm{a}_{p}$ と終了時点のき 裂長さ $\mathrm{a}_{f}$, 及び応力拡大係数一き裂伝ぱ速度のき裂伝ぱ特 性の関係式から評価することができる。

腐食環境下の疲労寿命となると, 腐食孔の形成によって き裂の発生過程が促進されるか否か，あるいはき裂面に掠 ける腐食生成物によってき裂の伝ぱ過程が抑制されるか否 かなどに大きく依存する。しかし，伝ぱ過程の寿命を決め る伝ぱ速度は, 平均応力が高く, き裂先端が十分に開口し た状態では, 環境や材料自身の強度などの条件に対して, 鈍感な性質を示すことが知られている゙。
腐食耐久寿命は, 腐食孔形成を含むき裂の発生寿命及び き裂の伝ぱ寿命の合計である。腐食孔を含むき裂発生過程 への影響因子は複雑であるとともに, その過程の損傷状態 を定量的に捉えることは困難である。しかし, 伝ば過程に あるき裂が存在する状態は, 大気中での残存耐久試験によ り，き裂の長さとして損傷状態を捉えることができる。残 存寿命で評価したき裂長さが相対的に小さければ，それま でに受けた腐食条件, 力学条件に対して耐久性が優れてい ると判断することができる。

\section{2 残存寿命によるき裂長さの評価}

\section{2 .1 裂伝ぱ速度とき裂伝ぱ寿命}

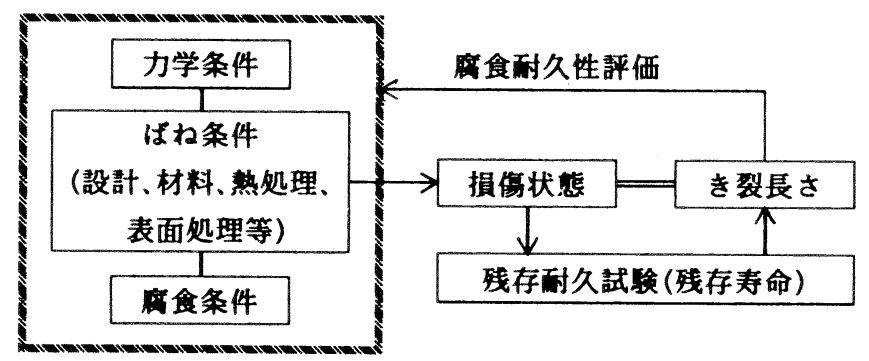

図 12 腐食耐久性評価の考元方

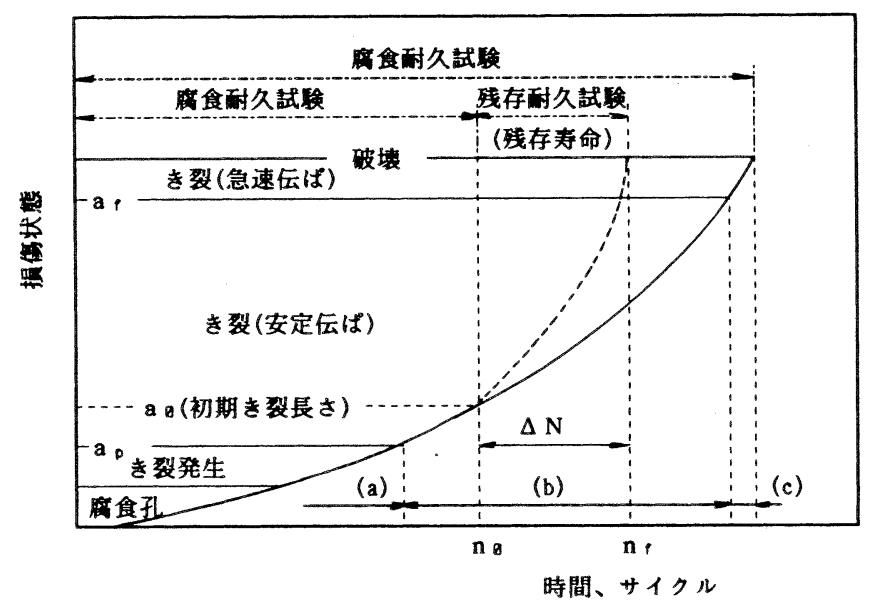

図 13 腐食疲労損傷過程

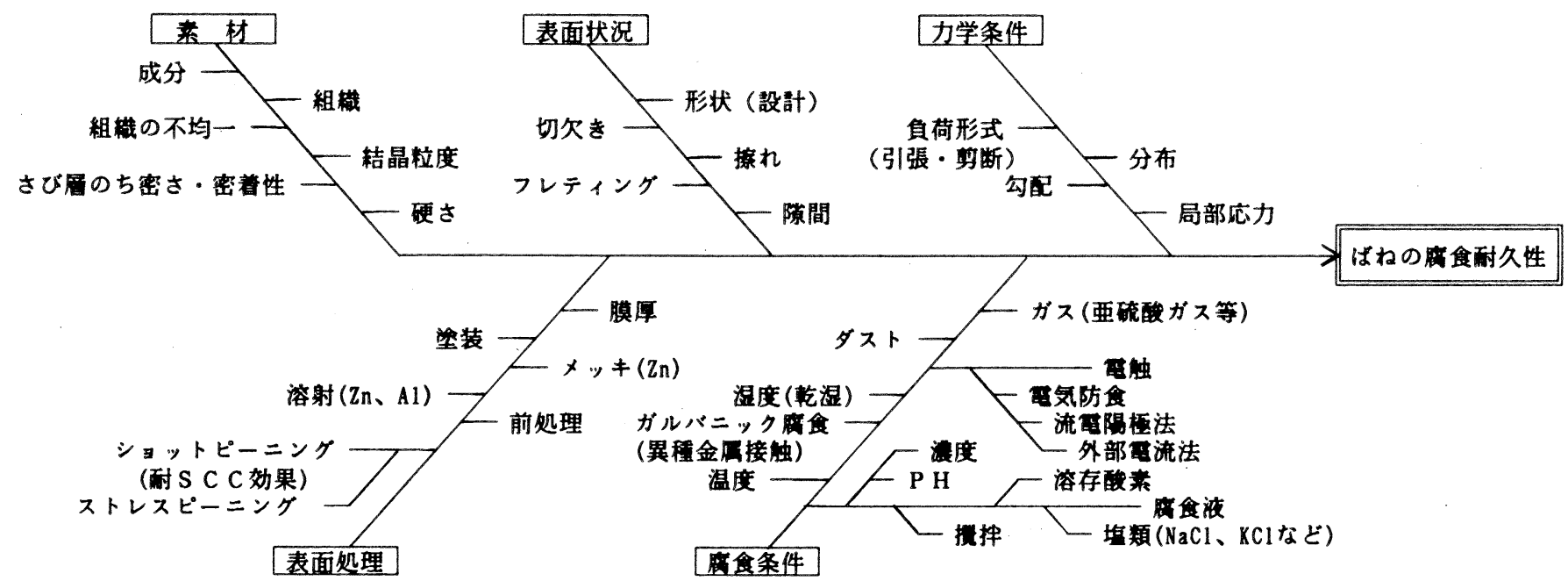

図 11 ばねの腐食耐久性を左右する要因 
安定して伝ぱする疲労き裂の 1 サイクル当りの伝ぱ速度 $d a / d n$ は，き裂先端の応力拡大係数範囲 $\Delta K$ に支配され， 両者の関係はパリス則とよばれる式（1）で表される。

$$
d a / d n=C(\Delta K)^{m}
$$

ここで, $\Delta K$ は応力範囲 $\Delta \sigma$, き裂長さ $a$, 及びき裂形状に 支配される係数 $F に$ 依存し

$$
\Delta K=F \Delta \sigma \sqrt{\pi a}
$$

で表される。なお，式（1）の成り立つ $\Delta K$ には範囲があり， ある值以下の $\Delta K$ ではき裂は伝ぱしない。このような $\Delta K$ の值をき裂伝ぱの下限界值 $\Delta K_{t h}$ と呼んでいる。き裂伝ぱ特 性の模式図を図14 に示す。

いま図 13 において，残存耐久試験の繰返し数 $n_{0}$ から $n_{f}$ の間 $\Delta N\left(n_{f}-n_{0}\right)$ に，き裂は $a_{o}$ から $a_{f}$ の長さに成長したと すると，両者の関係は

$$
\begin{aligned}
& \Delta N=\int_{n_{o}}^{n_{f}} d n \\
& =\int_{a_{0}}^{a_{f}} \frac{1}{C \pi^{m / 2} F^{m}}(\Delta \sigma)^{-m} a^{-m / 2} d a \\
& =\frac{2}{C \pi^{m / 2} F^{m}(m-2)(\Delta \sigma)^{m}} \times\left(\frac{1}{a_{o}^{(m-2) / 2}}-\frac{1}{a_{f}^{(m-2) / 2}}\right)
\end{aligned}
$$

で表される。ここで，Fはき裂長さ $a_{0}$ から $a_{f}$ の間でき裂長 さに依存しないと仮定している。 $\Delta N$ を残存寿命とし, 最 終段階のき裂長さ $a_{f}$ 老仮定することができるならば，残存 耐久試験開始時のき裂長さ $a_{0}$ は

$$
a_{o}=\left\{\frac{C \pi^{m / 2} F^{m}(m-2)(\Delta \sigma)^{m}}{2} \Delta N+\frac{1}{a_{f}^{(m-2) / 2}}\right\}^{2 /(2-m)}
$$

として，推定することができる。なお，仮定する $a_{f}$ の值が 多少異なっても評価される $a_{0}$ への影響は小さいことがわか っている。

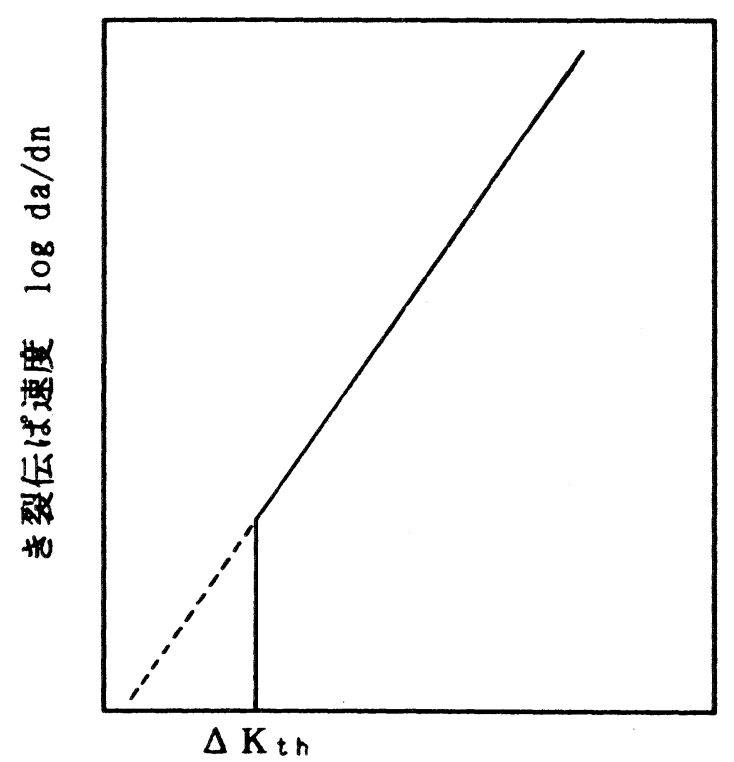

応力搪大係数筑囲 $108 \Delta \mathrm{K}$

図 14 き裂伝ぱ特性の模式図
式（1）における指数, 係数の值は, 応力比 0 の条件下で ばね鋼について調べた小山ら の) の結果によると, 平均的に は， $\Delta K$ の単位を $\mathrm{kgf} / \mathrm{mm}^{3 / 2}$ ，き裂伝ぱ速度 $d a / d n$ の単位 を $\mathrm{mm} /$ cycle として，

$$
m=3, \quad C=10^{-10}
$$

となっている。また， $\Delta K_{\text {th }}$ の值は応力比などに依存するが， 鋼種などによってはあまり変化しないといわれており，小 山ら ${ }^{4)}$ のまとめによると，応力比が 0 の場合， $10 \mathrm{kgf} / \mathrm{mm}^{3 / 2}$ の值が示されている。

\subsection{2 き裂長さの評価}

（1）板ばねの場合板ばねの場合を想定すると，曲げ による残存耐久試験により得られる残存寿命から，残存耐 久試験開始時に存在していたき裂の深さ方向の長さを評価 することができる。以下にその方法を示す。

（a）仮定板ば敉を想定し，リーフに扔けるき裂の状 態を図15に示す。

応力形式とき裂形態：リーフの軸に直角な半楕円表面き 裂に，片振り曲げ応力が作用

伝ぱ速度式： $d a / d n=C(\Delta K)^{m}$ $m=3, C=10^{-10}$

き裂伝ぱ下限界值： $\Delta K_{\text {th }}=10 \mathrm{kgf} / \mathrm{mm}^{3 / 2}$

アスペクト比 $: \mu=0.5(a / b)$

ポアソン比： $v=0.3$

破断：き裂先端が板厚の $1 / 2$ になったとき

応力拡大係数： $\Delta K=F \Delta \sigma \sqrt{\pi a}$ ここで $F$ は，有限板にお ける半楕円表面き裂の曲げによる応力拡大係数の形状係数 で，次式に示すように，アスペクト比及び板厚 $t$ に対する き裂深さの比 $\lambda=a / t$ に依存する ${ }^{5)}$ 。

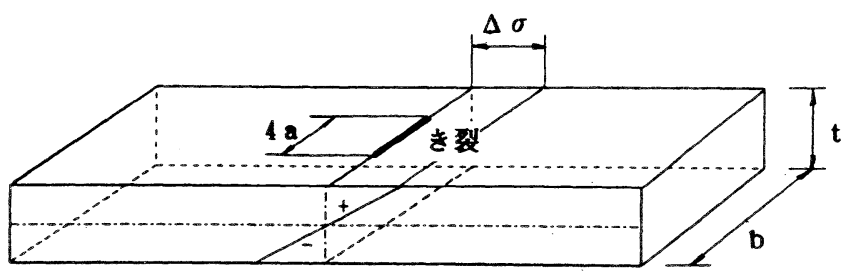

(1) 全体図

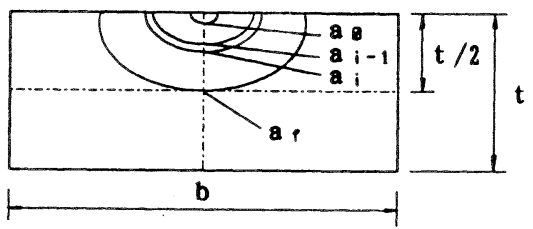

(2) き裂面断面

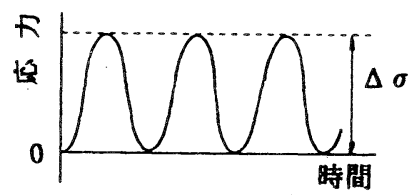

（3）き裂側表面の応力形式

図 15 曲げを受けるリーフの表面き裂 


$$
\begin{aligned}
F & =1.1359-0.3929 \mu-0.3440 \mu^{2}+0.2613 \mu^{3} \\
& +\lambda\left(-1.5184+0.4178 \mu+0.7846 \mu^{2}-0.6329 \mu^{3}\right) \\
& +\lambda^{2}\left(4.3721-13.9152 \mu+16.2550 \mu^{2}-6.4894 \mu^{3}\right) \\
& +\lambda^{3}\left(-3.9502+12.5334 \mu-14.6137 \mu^{2}+5.8110 \mu^{3}\right) \\
& (v=0.3,0.125 \leqq \mu \leqq 1.0, \lambda \leqq 0.6)
\end{aligned}
$$

(b) 計算＼cjkstart計算の流れを図16に示す。

応力範囲 $\Delta \sigma\left(\mathrm{kgf} / \mathrm{mm}^{2}\right)$, 板厚 $t(\mathrm{~mm})$, 残存寿命 $\Delta N$ を 入力。

き裂長さ $a_{0}$ を仮定：例えば $a_{o}=0.01 \mathrm{~mm}$

$$
\begin{aligned}
& a_{i}=a_{i-1}+0.01 \\
& \lambda=\left(a_{i}+a_{i-1}\right) / 2 t \text { として } F \text { を計算。 }
\end{aligned}
$$

き裂長さが $a_{i-1}$ から $a_{i}$ になるまでに要する繰返し数 $N_{i}$ を 式 (3) により計算。

$a_{i}$ が $t / 2$ になる前に $\Sigma N_{i}>\Delta N$ になったら，仮定した き裂長さが小さすぎたことを意味するので, 計算を打ち 切る。

き裂長さ $a_{o}$ を仮定し直す：例えば $a_{o}=0.02 \mathrm{~mm}\left(a_{o}\right.$ の仮 定の工夫により結果を速く出すことができる。）

計算を繰返す。

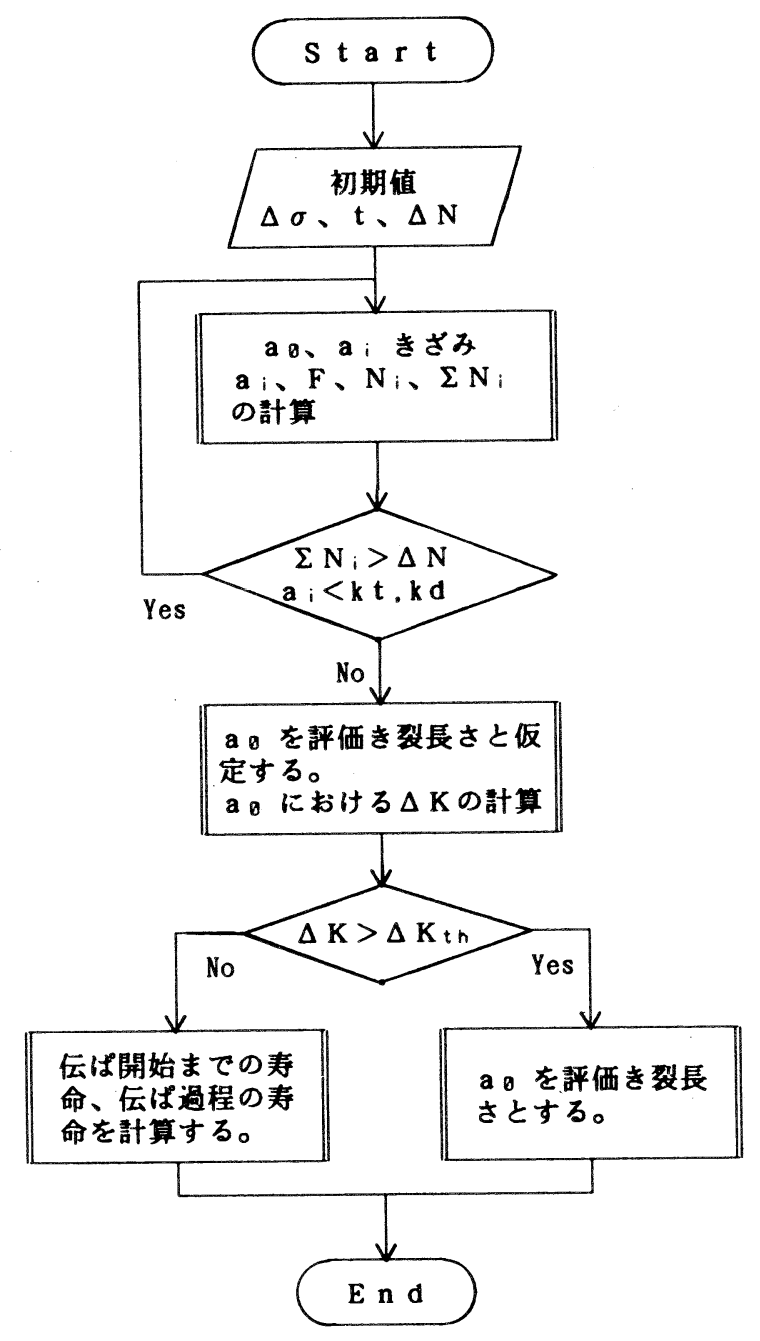

図 16 評価き裂長さの計算の流れ
最初に $a_{i}>t / 2$ となったときに， $\Sigma N_{i}>\Delta N$ になる場合の $a_{o}$ をき裂長さとする。

なお，き裂長さ $a_{0}$ に対する応力拡大係数 $\Delta K_{a o}=F \Delta \sigma \sqrt{\pi a_{0}}$ をを計算し， $\Delta K a_{0}<\Delta K_{\text {th }}$ となるならば，この場合は図 14 の点線の領域すなわち $\Delta K_{\text {th }}$ 以下でも伝ぱするとして $a_{0}$ を計 算したことになる。この場合，設定応力のもとでの $\Delta K_{\text {th }}$ に 対応するき裂長さを $a_{p}$ とすると， $a_{p}$ 以降パリス則による伝 ぱ寿命 $N_{p}$ を求めることができる。 $\Delta N-N_{p}$ は $a_{p}$ になるまで の過程の寿命 $N_{i}$ となる。ただし， $a_{p}$ は試験応力に依存した 值になる。

(c) 解析例 表 4 に示方残存耐久試験の結果のうち, 破断位置の応力範囲がわかっている一部のデー夕に上記の 手法を適用し，き裂長さを推定した。図17に腐食孔深さと 評価き裂長さとの関係を示す。腐食孔深さは，破断部近傍 で観察された腐食孔の最大の深さを表す。残存耐久試験の 破壊の起点となったき裂の長さは，その近傍で観察される 腐食孔の最大深さと必ずしも一致するものではないが，近 い值にあるものと予想される。両者は良い対応関係にあり， き裂長さの推定方法が妥当なものであることを示している。

（2）コイルばねの場合、コイルばねの場合はかなり大 胆な仮定のもとではあるが，コイルばねの残存耐久試験に より得られる残存寿命から，残存耐久試験開始時に存在し ていたき裂の深さ方向の長さを評価することができる。以 下にその方法を示す。

（a）仮定応力形式とき裂形態：丸棒の軸に直角な半 楕円表面き裂に，せん断応力と同じ大きさの片振り曲げ応 力が作用

伝ぱ速度式，き裂妘ぱ下限界值，アスペクト比，ポアソ ン比：板ばねの場合と同じ

破断：き裂先端が線径の $1 / 5$ になったとき

応力拡大係数： $\Delta K=F \Delta \sigma \sqrt{\pi a}$ ここで $F$ は，丸棒におけ る半楕円表面き裂の曲げによる応力拡大係数の形状係数で,

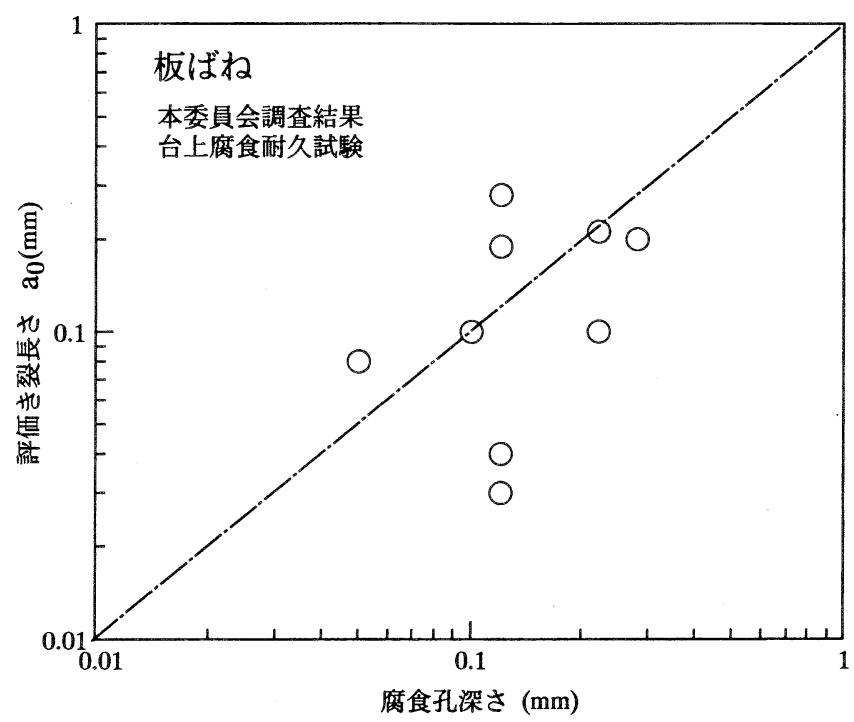

図 17 板ばねにおける残存耐久試験より求められる評価き裂長 さと腐食孔深さとの関係 
次式に示すように，アスペクト比 $\mu$, 直径 $d$ に対するき裂 深さの比 $\lambda=a / d$ に依存する

$F=\left(1.122-0.230 \mu-0.901 \mu^{2}+0.949 \mu^{3}-0.280 \mu^{4}\right)$

$\times\left(1.0+0.157 \times 2 \lambda-0.634 \times 4 \lambda^{2}+4.590 \times 8 \lambda^{3}-6.628 \times 16 \lambda^{4}\right)$

$\times\left(1.121-1.199 \lambda+4.775 \lambda^{2}-1.628 \lambda^{3}-7.035 \lambda^{4}+13.27 \lambda^{5}\right)$

/ $\left(1.12-0.231 \lambda+10.55 \lambda^{2}-21.72 \lambda^{3}+30.39 \lambda^{4}\right)$

(b) 計算計算の流れは図 16 に示す板ばねの場合と 同じである。

応力範囲: $\Delta \sigma\left(\mathrm{kgf} / \mathrm{mm}^{2}\right)$, 線径 : $d(\mathrm{~mm})$, 残存寿命： $\Delta N$ 大力。

以下 $F$ の計算，破断条件以外は板ばねの場合と同じ。

(c) 解析例

「懸架ばねの腐食疲労試験法に関する研究」 ${ }^{1)} に$ 記載のデ ー夕に適用した結果を図 18 に示す。腐食孔深さと評価き 裂長さの関係は良い対応関係にあり，き裂長さの推定方法 が妥当なものであることを示している。

\subsection{3 残存寿命と評価き裂長さとの関係}

ここで，リーフ板厚あるいはコイル線径と応力範囲が決 まると，残存寿命と評価き裂長さとは 1 対 1 に対応するの で，予両者の関係を求めておくと便利である。図 19 に残 存寿命と評価き裂長さの関係の 2,3 の例を, リーフ板厚, 線径，応力範囲をパラメータとして示す。

リーフ板厚を $8 \mathrm{~mm}$ と，㐫力範囲を 5 水準に変えた結 果を実線で示す。残存寿命が小さい領域で評価き裂長さが $4 \mathrm{~mm}$ に漸近する傾向にあるのは，破断条件を板厚の $1 / 2$ としたためである。同じ評価き裂長さに対する残存寿命は， 応力範囲が低い条件ほど長くなる。また，パリス則にのっ とり伝ぱを開始する限界のき裂長さ $a_{p}$ は, 応力範囲が低い ほど大きな值になる。したがって，残存耐久試験の応力条 件の設定に際して，損傷がわずかで短いき裂しか存在しな いと予想される場合は，試験時間の短縮を図るためと，存 在するき裂を伝ぱ過程のき裂として評価するために，高応

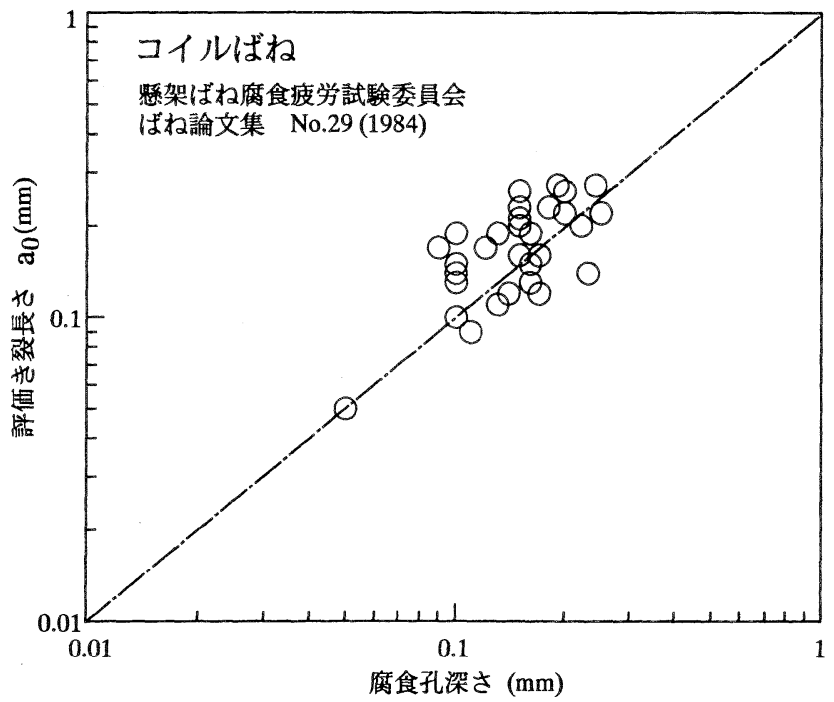

図 18 コイルばねに抢ける残存耐久試験より求められる評価き 裂長さと腐食孔深さとの関係
力の条件を選択することが必要である。

点線で示すリーフ板厚 $12 \mathrm{~mm}$ の結果との比較において は，き裂長さの長い領域では破断の設定条件を反映して両 者異なるが，1 mm 以下のき裂に対しては両者は近い結果 を与えている。

一点鎖線で示す線径 $12 \mathrm{~mm}$ のコイルばねの結果を板ばね の結果と直接比較することはできないが，評価き裂長さが 短い領域では, リーフ板厚 $12 \mathrm{~mm}$ の結果に近くなる。

\section{3 評価き裂長さの大小による腐食耐久性の評価}

以上のように，残存耐久試験を行うまでに受けた損傷状 態を，き裂長さという值で残存寿命より評価することがで きた。そこで図 12 にも見られるように，同じ腐食条件，力 学条件のもとでの試験を実施した状態での評価き裂の大小 を比較することによって，腐食耐久性の相対的な評価が可 能と考えられる。

なお，同一の腐食・力学条件下で損傷を受けたばねの腐 食耐久性を比較するとき，残存寿命の大小で比較すること もできる。すなわち，残存寿命の長いばねの方が損傷を受 けにくかったと判断することになる。しかし，破壊の位置 が異なるような場合は，破壊の起点部に作用する実応力は 異なるので，単に寿命の大小で損傷状態の比較できるのか 疑問が残る。また，そこでの損傷の実体が何であるかは不 明のままである。しかし，残存寿命から破壞のもととなっ たき裂長さを評価し，その評価き裂長さの大小を比較すれ ば，同一の腐食・力学環境下で受けた損傷を，き裂という 損傷の実体で比較することができることになる。すなわち， 比較する複数のばねにおいて，評価き裂長さが相対的に小 さければ，そのばねは所定の腐食・疲労環境下で損傷を受

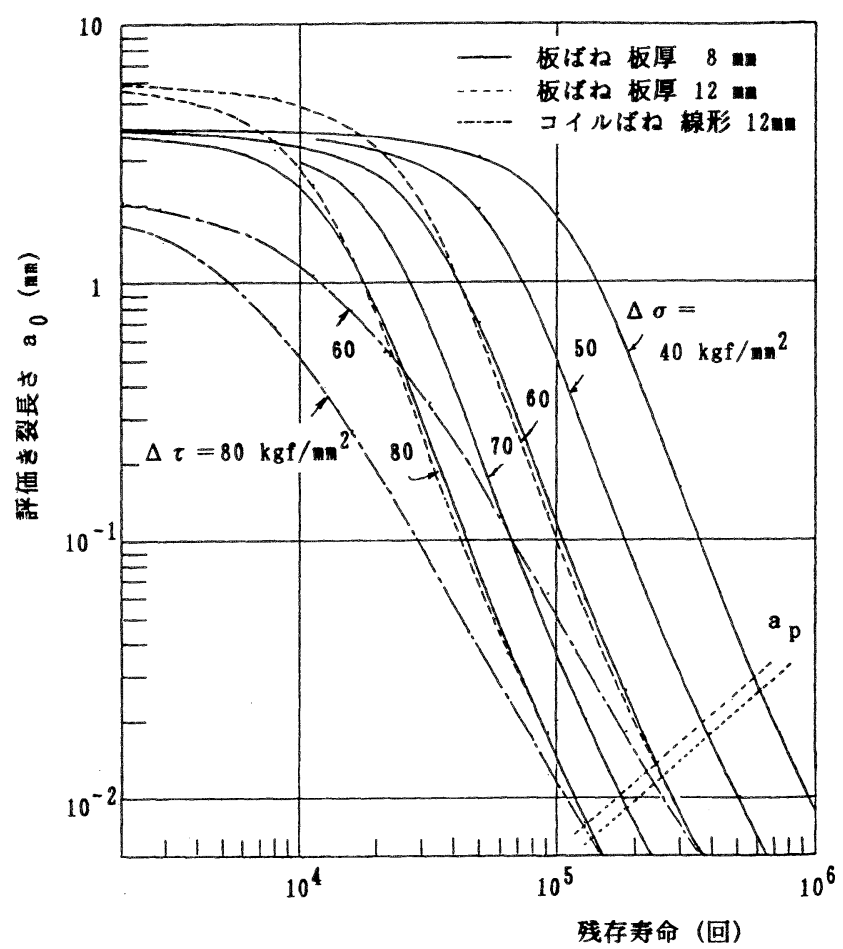

図 19 評価き裂長さと残存寿命との関係 
け難かったということで，他のばねより腐食耐久性が優れ ていると判断することができる。

また，ここではき裂長さを推定するとき，き裂伝ぱ特性 を仮定した。材質を変えてばねの腐食耐久性の改善を図ろ う，あるいは，ショットピーニングなどの表面処理の条件 を变えてばねの腐食耐久性の改善を図ろうとした場合など は，伝ぱ特性自身変わったり，残留応力の相違などにより， 仮定したき裂伝ぱ特性を用いたのでは真のき裂が推定でき ないのではないかとの懸念が残る。それは事実である。し かし，仮定したき裂伝ぱ特性を一つの「物差し」として用 いるのであれば，そこで得られた評価き裂長さは，真のき 裂の長さでなくても，その大小による相対的な比較は可能 である。

例えば，き裂伝ば速度が遅くなる新しい材料をばねに適 用し，従来のばねと比較する場合，当然新しいばねは伝ぱ 過程に時間を要するため, 残存寿命は長くなる。そこに, 仮定した伝ぱ特性の「物差し」を用いて評価き裂長さを求 めるとそれは短くなり，優れたばねと評価される。むしろ， 「物差し」となるき裂伝ぱ特性を仮定して評価き裂の長さを 求めることによって，その大小でばねの腐食耐久性の相対 的な比較が可能となる。なお，ここで仮定したき裂伝ぱ特 性は架空の特性ではなく，ばね鋼のデー夕を基礎にしたも のであり 、壮ねの耐久性を評価する際の「物差し」として は妥当なものと考えられる。

そのほかにも，評価き裂長さの大小による腐食耐久性を 評価する方法にはいくつかの利点がある。例えば試験工数 の削減や試験時間の短縮である。図 20 に試験形式として, 腐食耐久試験後の大気中における残存耐久試験の種々の組 合せを示す。なおこの図では，破断位置での応力範囲は同 一である場合を想定している。例えば，腐食耐久試験を破 断まで行わずに中断し，その後は大気中で連続して行える 残存耐久試験より求められる評価き裂長さ $a_{0}$ で耐久性を評 価することにする。応力範囲の条件が同じであると，既に述 ベたようにパリス則にのっとり伝ぱを開始するき裂長さ $a_{p}$

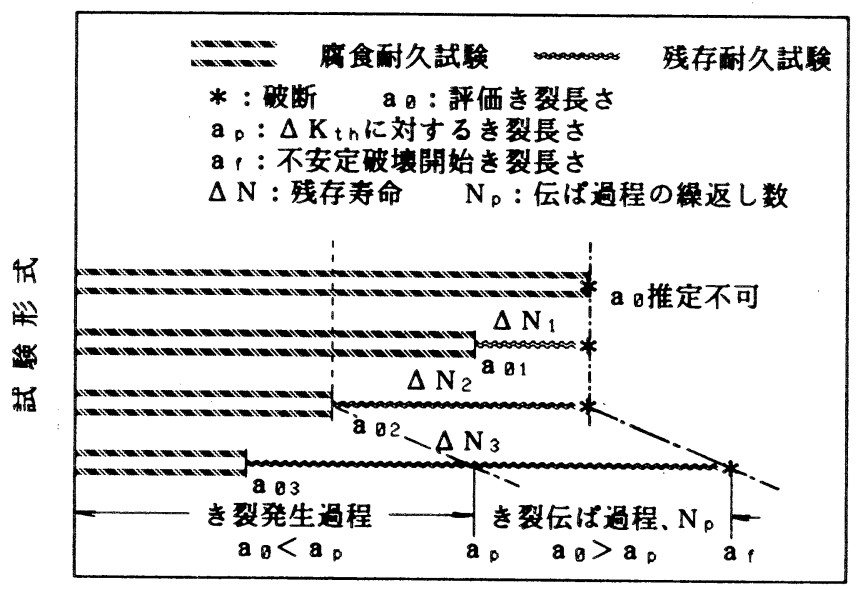

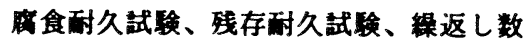

図 20 腐食耐久試験後の残存耐久試験により求められる 評価き裂長さ
になった後のき裂伝ぱ過程の寿命 $N_{p}$ は腐食環境でも大気中 でも大差ない。したがって，腐食環境下での試験はき裂が 長くなるまで行う必要はないので, 中断以降破断までに要 していた腐食耐久試験の腐食関連の工数, 試験時間の削減 が図れる。なお，大気中での残存耐久試験の応力条件は腐 食耐久試験の応力条件にそろえる必要はなく，大きくする こともできるので，この意味からも試験時間の短縮を図る ことができる。しかし，評価き裂長さが，設定応力のもと での $\Delta K_{t h}$ に対応するき裂長さ $a_{p}$ より小さい場合には，架空 のき裂長さを求めたことになるので，その值を比較しても 意味の無いこともあり，その場合は腐食耐久試験の条件を より厳しくするなどの配慮が必要である。

また別の観点からの利点としては，市場回収品などにつ いて, 残存耐久試験から評価き裂長さを求めることにより, 市場での使用環境状況などの推定, 検討が可能となること が挙げられる。

\section{5．台上腐食耐久試験}

\section{1 はじめに}

残存耐久試験の残存寿命より求める評価き裂長さの大小 により，腐食耐久性の評価が可能かどうかを検証するため, 表 7 に示す 4 件の事例について本評価法の適用を試みた。 最初の 3 件はすでに結果が明白なもので，期待される評価 結果が得られるかどうかを調べるものである。最後の 1 件 は必ずしも結果は明白ではなく，本評価法を適用した場合 にどのような評価結果になるかのケーススタディである。 なお, 以下の試験における試験片には, 塗装処理はしてい ない。

\section{2 試験内容と結果}

\section{2 .1 事例 1 (人工欠陥の大きさの相違)}

(1) 目的大きさの異なる人工欠陷を付けた試験片に 対して大気中で寿命試験を行った場合, 評価き裂長さの大 小が，欠陥の深さの大小と対応するかを確認する。

（2）試験条件供試材は硬さレベルをHV490とした SUP9 鋼で，試験片の寸法は $60 b \times 8 t \times 220 L$ ある。試験 片にはショットピーニング処理は施していない。

人工欠陷は，目標の深さを $0.4 \mathrm{~mm}$ と $1 \mathrm{~mm}$ にした 2 種 類を用意した。浅い欠陥は, 調質後, 人工欠陥を付ける箇 所をグラインダで研磨し, 研磨面を薄く樹脂で被覆し, ビ ッカース硬さ計で圧痕を付けて小さな穴を明け，その穴を 電解研磨で深くして作った。深い欠陥は, 調質前に $\phi 1.1$

表 7 検証試験の主旨

\begin{tabular}{|c|c|}
\hline 事例 & 評 価 対 象 項目 \\
\hline 1 & 人工欠陷の大きさの相连 \\
\hline 2 & 食・学条件の相遀 \\
\hline 3 & ショットピーニングの有無の相连 \\
\hline 4 & 硬さレベルの相連 \\
\hline
\end{tabular}


$\mathrm{mm}$ のドリルで究を明け, 調質後さらに $\phi 3 \mathrm{~mm}$ のドリルで 角を落として作った。人工欠陥は 4 点曲げ内スパンの荷重 点直下の板幅の中央に付けた。

疲労試験は図 21 に示すように, 4 点曲げ試験で, 大気中 に扔いて繰返し速度 $6.5 \mathrm{~Hz}$ のもとで行った。なお，内スパ ン長さ $A$ を $50 \mathrm{~mm}$, 外スパン長さ $B$ を $170 \mathrm{~mm}$ とした。試 験片中央部に貼付したひずみゲージによって応力を測定し， 所定の応力に対応するストロークを決めて，ストローク制 御で試験した。応力条件は $65 \pm 30 \mathrm{kgf} / \mathrm{mm}^{2}$ と $65 \pm$ $40 \mathrm{kgf} / \mathrm{mm}^{2}$ とした。

（3）結果同じ深さの欠陥材では応力条件が厳しくな ると，また同じ応力条件のもとでは人工欠陥の樑さが深く なると疲労寿命は低下した。破面写真を図 22 に示寸。目標 とした人工欠陥からき裂は発生・伝ぱし破断に至っていた。 人工欠陥の深さと寿命から求められる評価き裂長さとの関 係を図 23 に示す。プロットは必ずしも $45^{\circ}$ の線上にはない が，欠陥の深い試料の方が評価き裂の長さは大きくなって いる。したがって，評価き裂長さの大小が，欠陥の梁さの 大小と対応することが確認された。な扔，図 23 には結果を 応力条件別に記号を変えてプロットしているが, 評価き裂 長さの大小には試験応力条件の相違の影響は出ていない。

\section{2 .2 事例 2 (腐食・力学条件の相違)}

(1) 目的同一条件の試験片に対して異なる条件の腐 食耐久試験を行った場合，評価き裂長さの大小が，異なる 腐食条件, 力学条件による損傷状態の相違と対応するかを 確認する。

（2）試験条件供試材は硬さレベルを HV500とした SUP6 鋼で, 試験片の寸法は $70 \mathrm{~b} \times 8 \mathrm{t} \times 550 \mathrm{~L}$ である。試験 片にはショットピーニング処理は施していない。

腐食耐久試験は，塩水浸漬 0.5 時間 $(5 \% \mathrm{NaCl})$, 疲労試 験 $\left(65 \pm 30 \mathrm{kgf} / \mathrm{mm}^{2}, 2.6 \mathrm{~Hz}, 3,000\right.$ 回)，恒温槽放置23時 間 $\left(26^{\circ} \mathrm{C}\right.$ ，湿度 $95 \%$ ，無負荷）の 24 時間を 1 サイクルとし， $10 ， 15 ， 20$ サイクルの 3 条件を設定した。残存耐久試験は 大気中で，応力条件 $65 \pm 30 \mathrm{kgf} / \mathrm{mm}^{2}$ のもとで行った。腐食 耐久試験中の疲労試験及び腐食耐久試験後の残存耐久試験 は 4 点曲げ試験で，図 21 に示す内スパン A を $150 \mathrm{~mm}$, 外 スパン Bを $500 \mathrm{~mm}$ とした。試験の制御は事例 1 の場合と 同じで，試験片中央部の応力が所定の忍力になるストロー

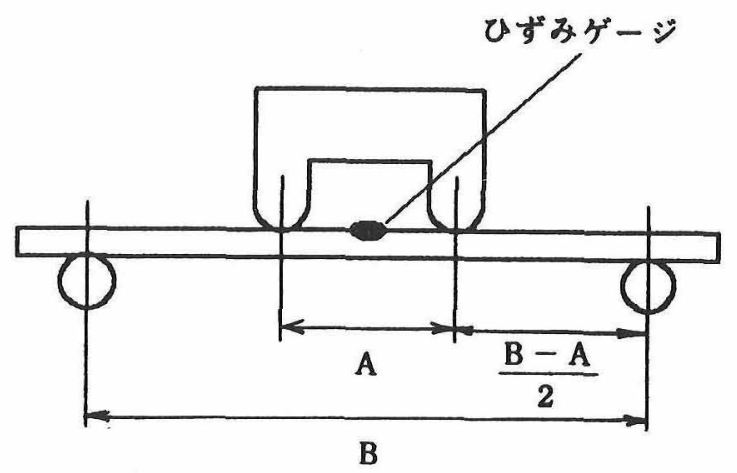

図 214 点曲げ疲労試験方法

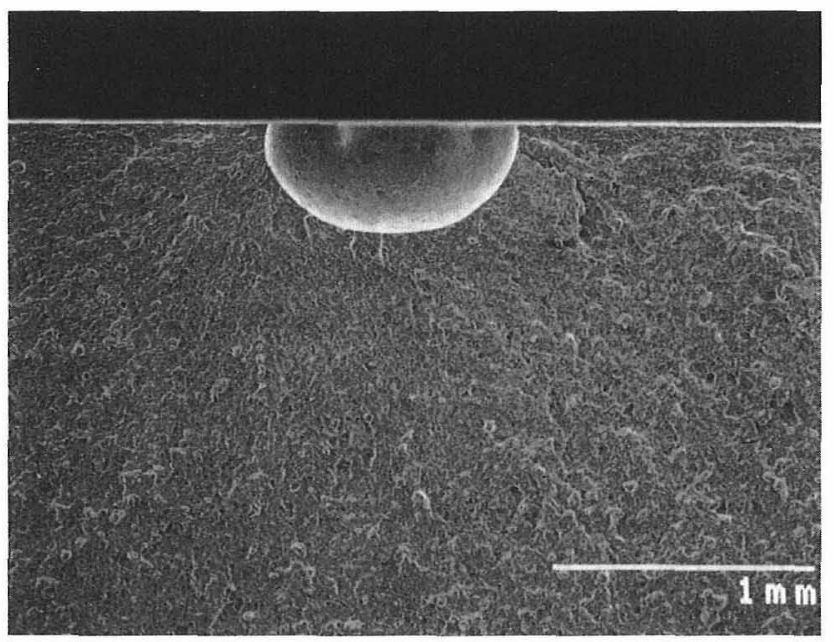

(1) $\sigma=65 \pm 40 \mathrm{kgf} / \mathrm{mm}^{2}, \mathrm{Nf}=33,170$

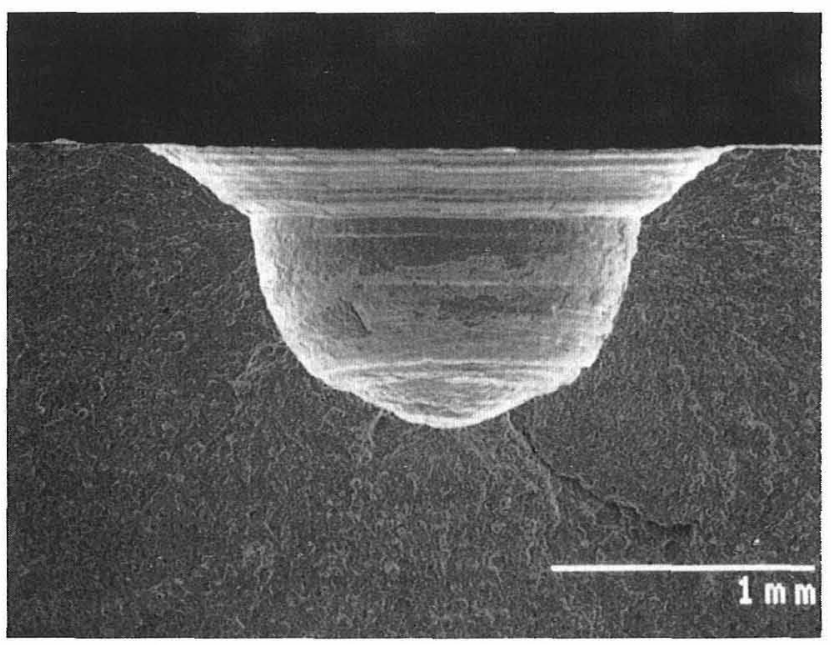

(2) $\sigma=65 \pm 35 \mathrm{kgf} / \mathrm{mm}^{2}, \mathrm{Nf}=49,880$

図 22 人工欠陥材の破面写真

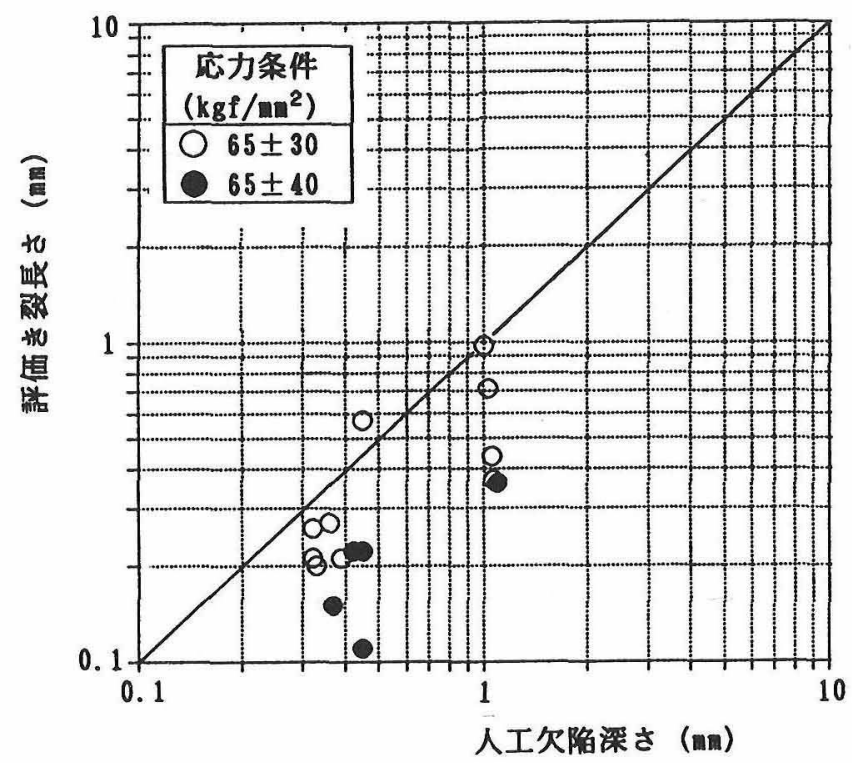

図 23 人工欠陥深さ（測定值）と評価き裂長さとの関係 
クを決めて，ストローク制御で試験した。

（3）結果破面のマクロ写真を図 24 の示す。腐食耐 久試験により形成されたき裂は着色され, 残存耐久試験で 伝ぱした領域と明瞭に区別できる。腐食耐久試験のサイク ル数が増すと損傷が進み，き裂が長くなっている。このよ うな損傷状態の相違が，残存寿命から求められる評価き裂 長さと対応するのか調べてみる。図 25 に腐食サイクル数と 評価き裂長さとの関係を示す。10，15，20サイクルと腐食 条件, 力学条件が厳しくなるにしたがい, 評価き裂長さは 長くなる。したがって，評価き裂長さの大小が，損傷状態 の相違と対応することが確認された。なお図 25 には, 破面 上で観察された腐食耐久試験により形成されたき裂長さが 合わせて示されているが, 評価き裂長さとは必ずしも一致 はしていない。

\section{2 .3 事例 3 (ショットピーニングの有無の相違)}

（1）目的ばね条件としてショットピーニング処理有 り無しの試験片に対して, 同一条件の腐食耐久試験を行っ

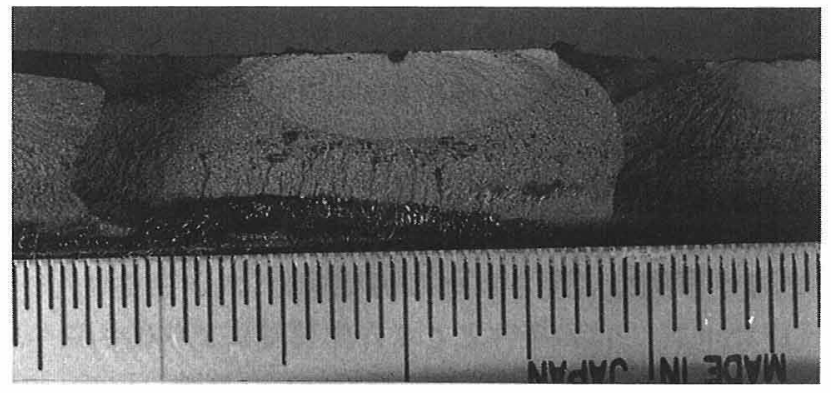

（1） 10 サイクル、残存寿命 $=34,000$

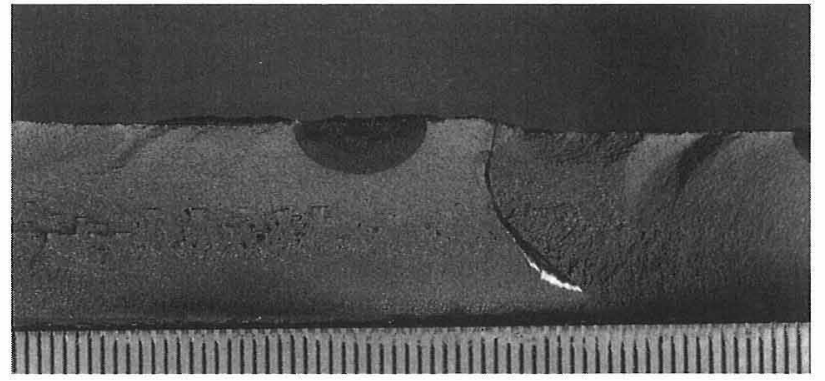

（2）15サイクル、残存寿命 $=10,500$

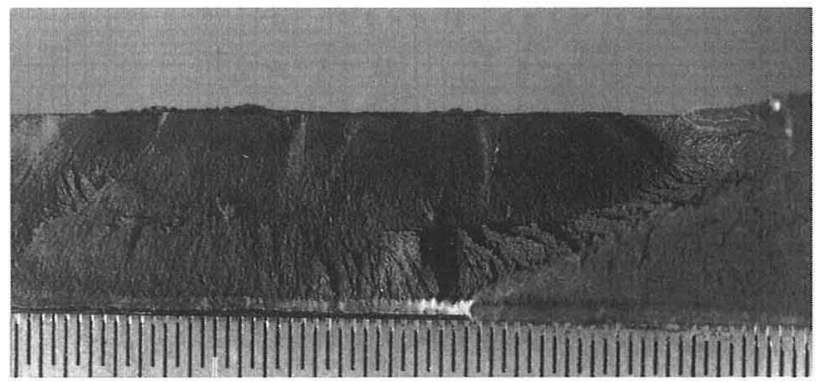

（3） 20 サイク、残存寿命 $=1,100$

図 24 ショットピーニング処理を施さない材料の腐食耐久試験 後の残存耐久試験による破面の巨視的様相（実物に最小メモリ $0.5 \mathrm{~mm}$ のスケールを添えた写真)
た場合，評価き裂長さの大小が，ショットピーニングの有 無による損傷状態の相違と対応するかを確認する。

（2）試験条件供試材は硬さレベルをHB444とした SUP9 鋼で，試験片寸法は $70 \mathrm{~b} \times 8 \mathrm{t} \times 550 \mathrm{~L}$ である。ショッ トピーニングによる表面圧縮残留応力は $64.1 \mathrm{kgf} / \mathrm{mm}^{2}$ とな つた。

比較するショトピーニングを施していない試験片の結果 としては, 硬さレベルがほぼ同じである事例 2 の結果を流 用することにする。したがって，ショットピーニング材の 腐食耐久試験の条件及び試験方法は事例 2 の場合と同じと した。なお一部，腐食耐久試験を加えない疲労試験と，破 断までの腐食耐久試験を行った。

また，腐食耐久試験の応力条件が $65 \pm 30 \mathrm{kgf} / \mathrm{mm}^{2}$ ではな く, $65 \pm 40 \mathrm{kgf} / \mathrm{mm}^{2}$ とした試験も行い，事例 2 の場合と同 様, 評価裂長さの大小が, 異なる腐食条件, 力学条件によ る損傷状態の相違と対応寸るかを確認した。なお，この試

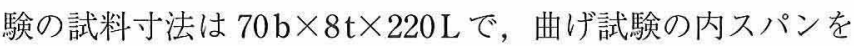
$50 \mathrm{~mm}$ ，外スパンを $170 \mathrm{~mm}$ とした。

(3) 結果破面のマク口写真を図 26 の示す。図 24 に 示すショットピーニングを施していない試験片の結果に比 ベ，同じサイクルの腐食耐久試験で受ける損傷すなわち形 成されたき裂の長さは小さくなっている。

図27にショットピーニング処理の有無と評価き裂長さと の関係を示す。10，15，20 サイクルの各環境・力学条件に おいて，ショットピーニングを施した試験片の評価き裂辰 さは短くなる。したがって，評価き裂長さの大小が損傷状 態の相違と対応することが確認された。この結果により， 実施したショットピーニング妈理により，当該腐食耐久環 境下での腐食耐久性は向上したと判断することができる。

図28の横軸は残存耐久試験の残存寿命及び腐食耐久試験 における疲労条件の繰返し数を含めた全寿命を表し，縦軸 は残存寿命から求められる評価き裂長さ及び腐食耐久試験 で形成されたき裂長さの実測值を表している。ここで，

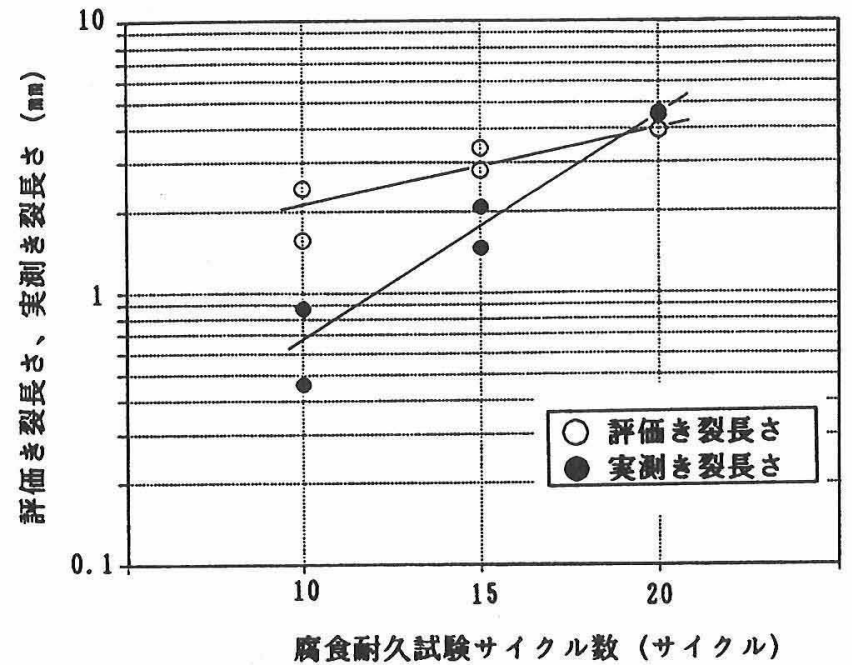

図 25 ショットピーニング処理を施さない材料の腐食耐久試験 サイクル数と評価き裂長さとの関係 


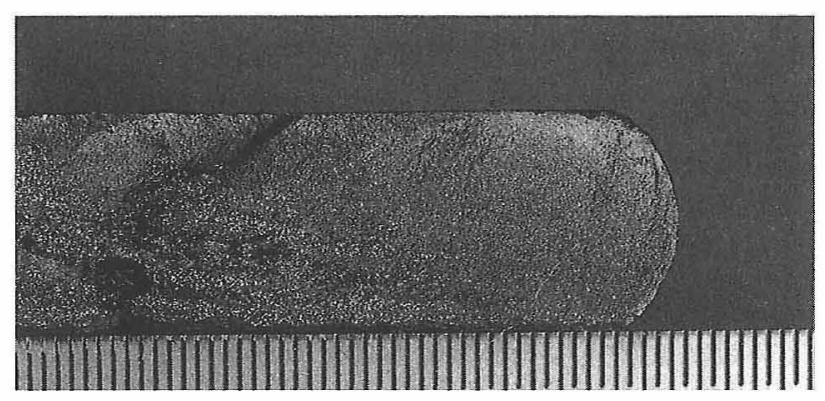

（1）10サイクル、残存寿命 $=373,200$

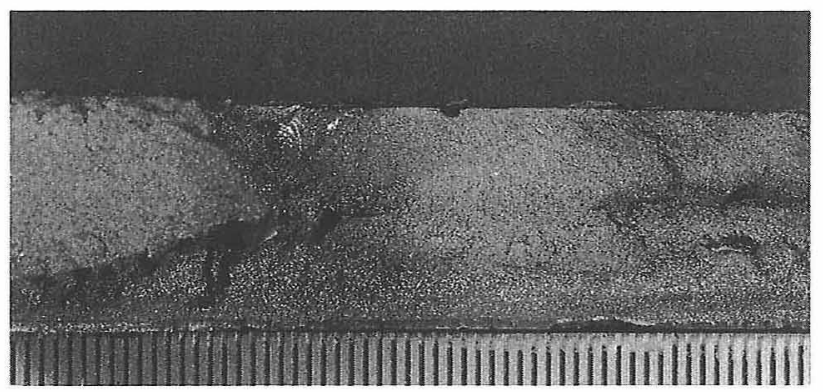

（2）15サイクル、残存寿命 $=69,000$

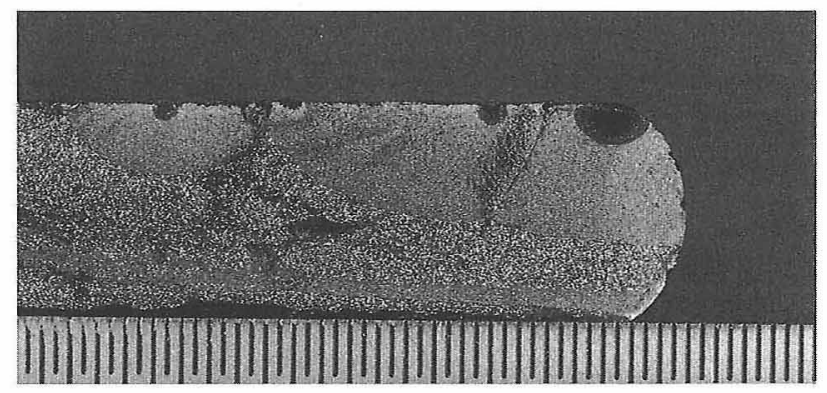

（3） 20 サイクル、残存寿命 $=29,000$

図 26 ショットピーニング処理を施した材料の腐食耐久試験後 の残存耐久試験による破面の巨視的様相（実物に最小メ モリ0.5mmのスケールを添えた写真)

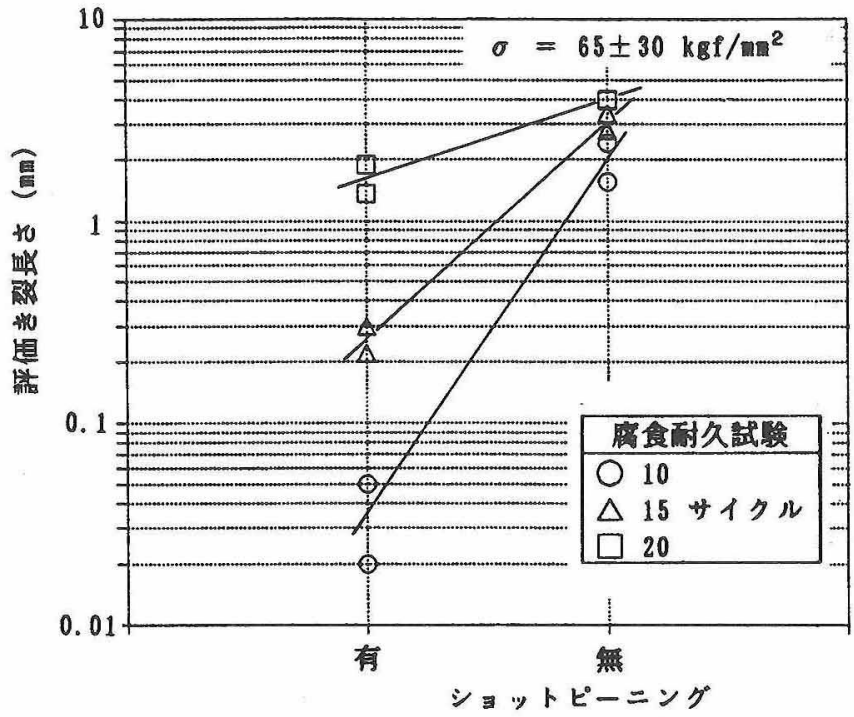

図 27 ショットピーニング処理の有無と評価き裂長さとの関倸
評価き裂長さは実線で，残存寿命は黒印，全寿命は白印で 示してある。事例 2 ですでに述べたショットピーニング処 理を施さない場合と同様，処理材でも腐食耐久試験のサイ クル数が增え, 腐食条件, 力学条件が厳しくなるにしたが い，評価き裂長さは長くなり，評価き裂長さの大小が，損 傷状態の相違と対応していることがわかる。

同図において，サイクル数が $24 ， 27$ とあるのは，破断ま で腐食耐久試験を行った結果で，それぞれ25，28サイクル 目の疲労条件下での寿命を残存寿命としてプロットしたも のである。これらの結果を含め, 全寿命についてみると， ショットピーニング処理材，未処理材ともある程度以上の 大きさのき裂が形成されると，腐食耐久試験のサイクル数 の大小に係わらず全寿命はほぼ一定になることがわかる。 これは，図20においても述べたように，同じ応力条件のも

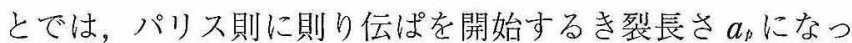
た後のき裂伝ぱ過程の寿命 $N_{p}$ は，腐食環境下でも大気中で も大差ないということを実験的に示したことになる。

また，ショットピーニング材で腐食耐久試験の応力条件 を $65 \pm 30 \mathrm{kgf} / \mathrm{mm}^{2}$ とした結果と， $65 \pm 40 \mathrm{kgf} / \mathrm{mm}^{2}$ のとした 結果を比較すると，図 29 に示すように，10，15，20 サイ クルの各腐食耐久試験とも, 力学条件が厳しくなると, 評 価き裂長さは長くなった。したがって，評価き裂長さの大 小が，事例 2 の場合と同様，異なる力学条件による損傷状 態の相違と対応することが確認された。

\section{2 .4 事例 4 （硬さレベルの相違）}

（1）目的ばね条件として，熱処理により硬さレベル を変えショットピーニング処理を施した試験片に対して, 同一条件の腐食耐久試験を行い, 評価き裂長さの大小で, 硬さレベルの高低による腐食耐久性の優劣が評価できるか 検討守る。

（2）試験条件＼cjkstart供試材は事例 3 の場合と同じ SUP9 鋼 で，硬さレベルをHB401と低くした。ショットピーニング による表面圧縮残留応力は $52.0 \mathrm{kgf} / \mathrm{mm}^{2}$ となった。したが って硬さレベルを HB444 とした事例 3 の結果と比較すると きは，単に硬さだけでなく，残留応力が変化していること や，以下に述べる試験片寸法が異なることにも留意しなけ

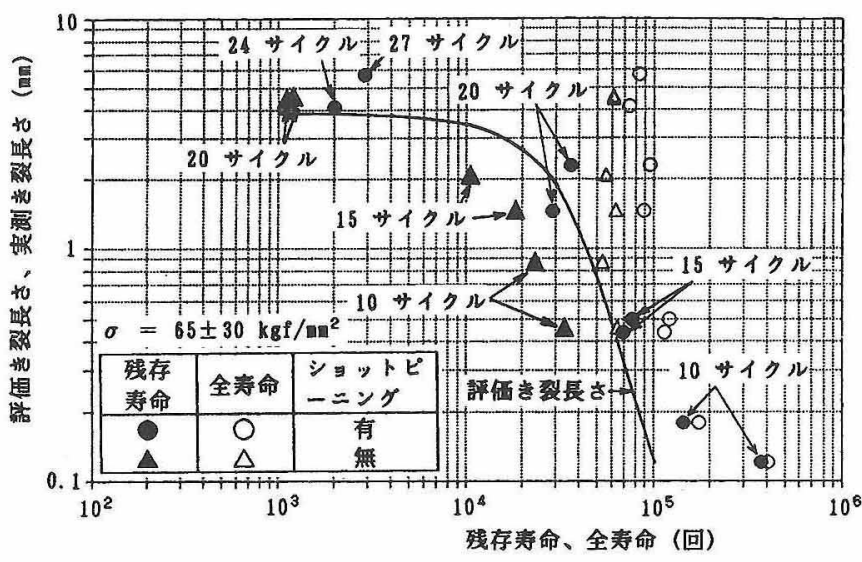

図 28 残存寿命、全寿命と評価き裂長さ、実測き裂長さとの関係 


\section{ればならない。}

腐食耐久試験の条件は事例 3 の場合と同様, 事例 2 の条 件と同じとした。腐食耐久試験の応力条件が $65 \pm$ $30 \mathrm{kgf} / \mathrm{mm}^{2}$ の場合の試料寸法は $70 \mathrm{~b} \times 8 \mathrm{t} \times 1200 \mathrm{~L}$ で, 曲げ 試験の内スパンを $80 \mathrm{~mm}$ ，外スパンを $900 \mathrm{~mm}$ とした。ま た，応力条件 $65 \pm 40 \mathrm{kgf} / \mathrm{mm}^{2}$ の試験の試料寸法は $70 \mathrm{~b} \times$ $8 \mathrm{t} \times 600 \mathrm{~L} て ゙$, 曲げ試験の内スパンを $100 \mathrm{~mm}$, 外スパンを $500 \mathrm{~mm}$ とした。

（3）結果硬さレベルの異なる材料に対する, 各腐食 耐久試験条件下の評価き裂長さの結果を図 30 に示す。 $\sigma=$ $65 \pm 40 \mathrm{kgf} / \mathrm{mm}^{2}$ の場合, 各腐食耐久試験のサイクルごとに 比較すると，硬さの高い方が評価き裂長さは小さくなる。 一方, $\sigma=65 \pm 30 \mathrm{kgf} / \mathrm{mm}^{2}$ の場合は, 逆に, 硬さの低い方 が評価き裂長さは小さい。したがってこの結果からは, 熱 処理により硬さレベルを変えると， $\sigma=65 \pm 40 \mathrm{kgf} / \mathrm{mm}^{2}$ の 場合は硬さの高い材料の方が， $\sigma=65 \pm 30 \mathrm{kgf} / \mathrm{mm}^{2}$ の場合 は硬さの低い材料の方が, 当該腐食耐久環境下での腐食耐 久性は優れていると判断される。

このように同じ材料に対しても，腐食耐久試験の応力条 件などによって腐食耐久性の評価結果が異なる場合もある。 このような結果をもたらす原因としては，先に述べたよう に, 硬さレベルを変えたことに伴うショットピーニング処 理による残留応力の相違や, 試験片形状の相違などが考え られるが，その詳細な検討は本報告の範囲ではない。硬さ レベルの影響など，個々の要因について厳密に明らかにす るには，詳細な実験計画のもとでの試験が必要となるが, 評価き裂の大小による腐食耐久性の評価は, 関連した要因 の影響を含めた，現実に即した総合的な判断を行う手がか りを与えるものとなる。

\section{3 結果の総括}

残存耐久試験の残存寿命より求められる評価き裂長さの 大小により腐食耐久性の評価が可能かどうかを検証するた

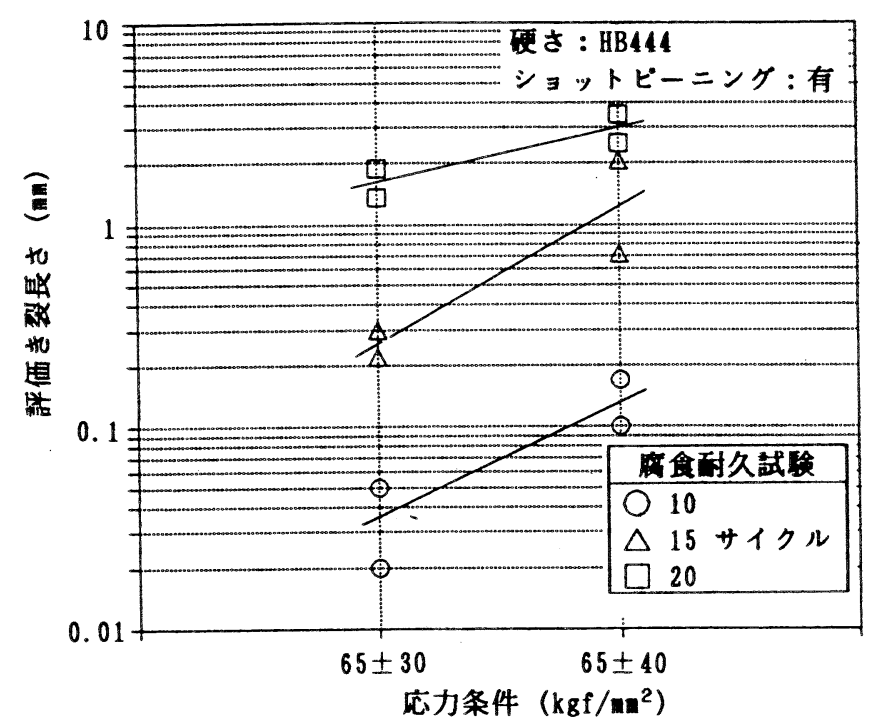

図 29 腐食耐久試験に扮ける応力条件と評価き裂長さとの関係
め, 表 7 に示す事例について試験，検討を行い以下の結果 を得た。

（1）寿命より求められる評価き裂長さの大小と人工欠陥 深さの深い, 浅いとは対応し, 残存寿命から, 残存耐久試 験開始時に存在するき裂長さの大小を評価できることが確 認された。

（2）10，15，20サイクルと腐食条件，力学条件が厳しく なるにしたがい, 残存寿命より求められる評価き裂長さは 長くなる。したがって，評価き裂長さにより，腐食・力学 条件が変わることによる損傷状態の相違が評価できること が確認された。

（3）ショットピーニング有無の供試材において，ショッ トピーニング有りの方が残存寿命より求められる評価き裂 長さは短くなる。したがって，評価き裂長さにより，ばね 条件が変わることによる損傷状態の相違が評価できること が確認された。

（4）硬さレベルの異なる材料の供試材に対しては, 腐食 耐久試験の応力条件によって，評価き裂長さの大小による 腐食耐久性の優劣の判定結果が逆転することがあった。

以上の結果により，残存耐久試験により求められる評価 き裂の大小の比較により，腐食耐久性の相対的な評価が可 能なことが確認された。今後はさまざまなばね条件, 腐食 条件及び力学条件に適用を試みるとともに, 相対的な評価 だけでなく，寿命で何％の向上が図れたのか，強度で何％ 上昇が見込まれるのか, などの定量的評価法についても検 討する必要がある。

なお，各事例の結果に扔いて，残存耐久試験から求めら れる評価き裂長さと，腐食耐久試験で形成されたき裂長さ の実測，あるいは久陥深さの関係を図 31 に示す。評価き

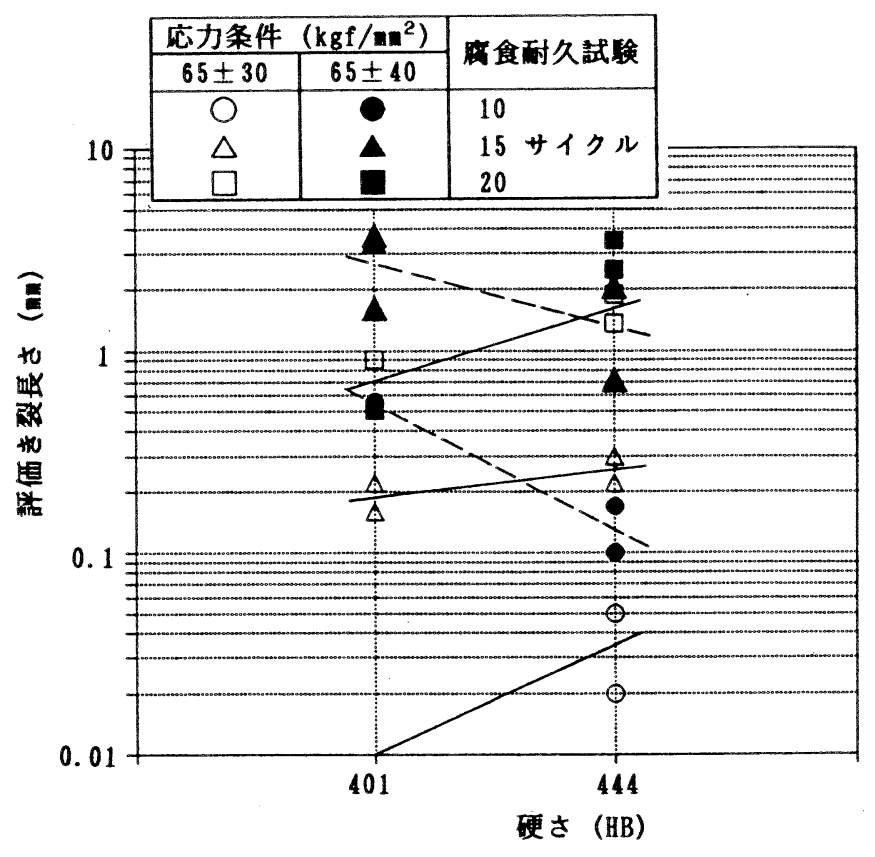

図 30 供試材の硬さレベルと評価き裂長さとの関係 
裂長さとき裂長さの実測値はほぼ $45^{\circ}$ の傾きの線に乗ってお り，「物差し」として用いたき裂伝ぱ特性の表示式により評 価したき裂長さは，ある程度実際のき裂長さを表現してい ることがわかる。しかし，ショットピーニング処理材の結 果が，評価き裂長さが小さいときに $45^{\circ}$ の線に対して下側 にきたり，人工欠陥試験片の結果が， $45^{\circ}$ の線に対して下側 にくるのは，真のき裂長さを求めるときには考虑すべき要 因のあることを示している。すなわち，前者の場合は，シ ヨットピーニングによる圧縮残留応力により伝ぱ速度が遅 くなり，残存耐久試験の残存寿命が長くなることを，また 後者の場合は疲労寿命に人工欠陥からのき裂の発生過程が 含まれことを，考慮しなければならない。

\section{6. 台上腐食耐久試験方案の提案}

以上の検討を踏まえ，以下にばねの台上腐食耐久性の評 価方法として「ばねの腐食耐久性能の相対的評価方法」を 提案する。

ばねの腐食耐久性能の相対的評価方法

1. 適用範囲

この方案は複数の種類の板ばねあるいはコイルばねにつ いて，特定の腐食環境下での腐食耐久性能の相対的優劣を， 残存寿命より求める評価き裂長さの大小によって評価する 方法について規定する。

\section{2. 評価手順}

\section{1 評価対象試料}

腐食耐久性能向上のため，材質，熱処理，表面処理，形 状，アッセンブルなどの条件をパラメータとして変えた板 ばねあるいはコイルばねを対象とする。

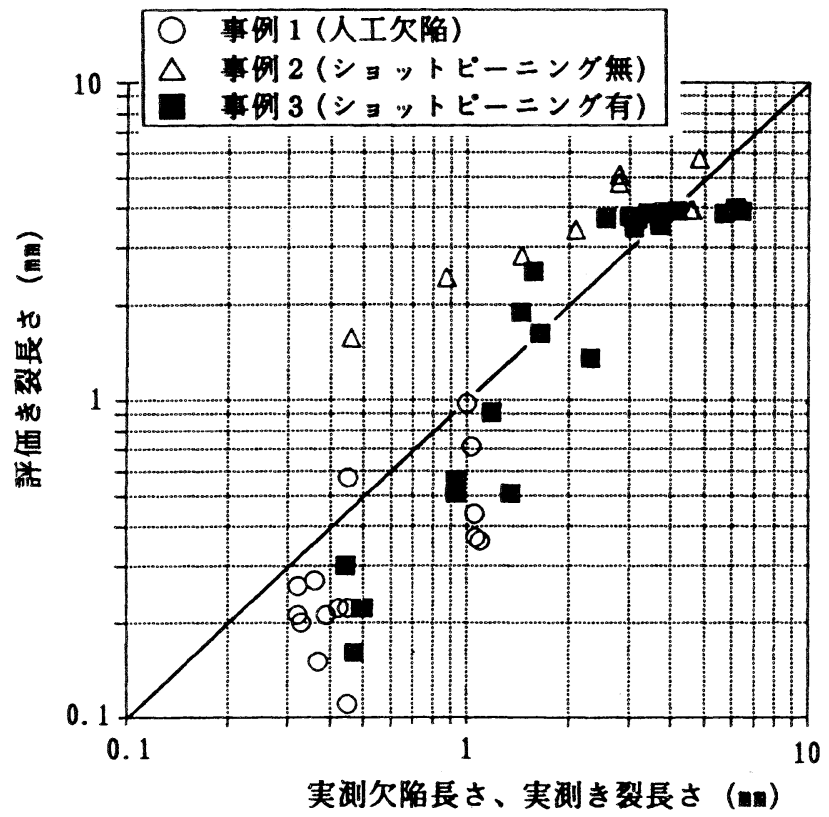

図 31 評価き裂長さと実測欠陥深さ、実測き裂長さとの関係
2.2 腐食環境，疲労環境の設定と腐食耐久中断試験の 実施

腐食環境，疲労環境の条件設定及び腐食耐久試験条件， 試験中断条件については，当事者間の協議により決める。

評価対象試料について，それぞれ同一条件の腐食耐久中 断試験を実施する。

同一ばねに対する繰返し数は 3 以上とし，具体的な数は 当事者間の協議により決める。

\section{3 残存耐久試験の条件設定と実施}

腐食耐久試験後，大気中で連続して破断までの疲労試験を 実施する。応力条件については当事者間の協議により決める。

2.4 腐食耐久中断試験により形成されるき裂長さの推定

残存耐久試験に打ける破壞起点部に作用寸る応力範囲， 残存寿命及び，板ばねリーフ板厚あるいはコイルばね線径 を用い，腐食耐久中断試験により形成されたき裂長さを評 価き裂長さとして計算により求める。

2.5 腐食耐久性能の相対的優劣の判定

評価対象試料の範囲において，腐食耐久中断試験後の残 存寿命より求められる評価き裂長さの短いばねほど，腐食 耐久性能が優れていると判定する。

\section{3. 評価結果の報告}

評価結果の報告には，次の事項について詳細な記録を付 記することが望ましい。

（1）ばねの諸元

(2) 腐食環境条件

(3) 疲労環境条件

(4) 腐食耐久試験条件

(5) 残存耐久試験条件

（6）残存耐久試験結果及び評価き裂長さの一覽表

(7) 判定結果

$$
\text { 4. 参 考 }
$$

評価き裂長さ計算プログラムを参考として付表に示す。

\section{7. あとがき}

2 年半にわたる委員会活動の成果として, 腐食耐久性の 評価の標準的な方案を提案することができた。今後はさま ざまなばね条件，腐食条件及び力学条件に適用を試み，不 備な点の改良を図るとともに，デー夕を蓄積し，デー夕べ 一スを構築していくことが，耐久性，信頼性のより優れた ばねの開発，高い安全性のもとでのばねの使用のために, 肝要と思われる。

\section{参 考 文 献}

1）菅野公一郎，ばね論文集，No.25，(1980), 39.

2）懸架ばね腐食疲労試験委員会，ばね論文集，No. 29, (1984), 115.

3）西島 敏ほか，金属材料技術研究所 研究報告集，No.6, (1987), 197 .

4）小山・博ほか，ばね論文集，No. 29, (1984), 30.

5) Y. Murakami et. al. : Stress Intensity Handbook, Vol.2, (1987) Pergamon Press. 
付表 評価き裂長さの計算プログラム

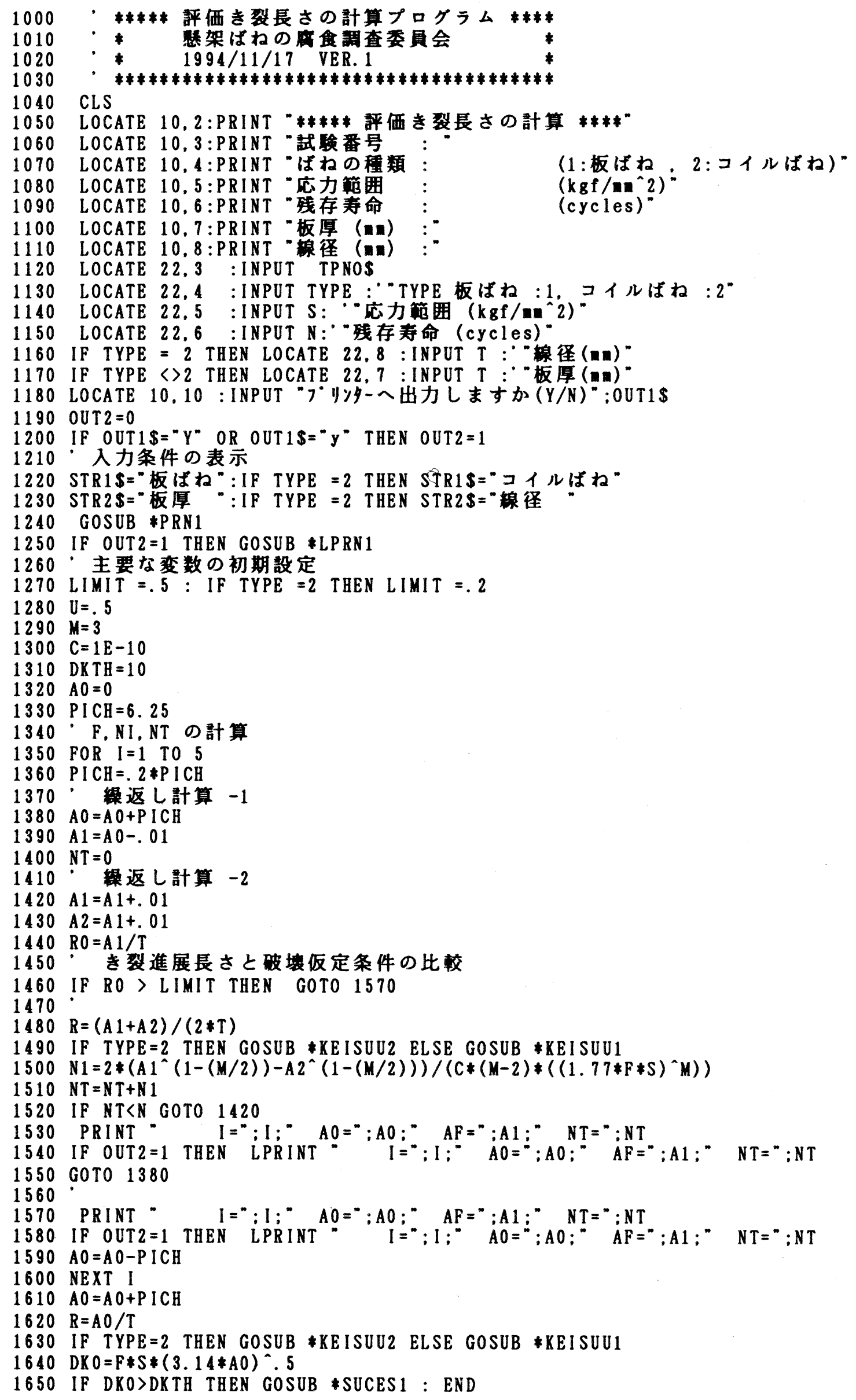


1660 ・伝ぱ開始までの寿命の計算

1670 PRINT - 評価き裂長さ(AO)

1680 IF OUT2 $=1$ THEN LPRINT " 評価き裂長さ $(\mathrm{AO} 0)=$ " $A 0$ :" (酉)

1690 FOR J=1 TO 10000

$1700 A O=A O+.001$

$1710 \mathrm{R}=\mathrm{AO} / \mathrm{T}$

1720 IF TYPE $=2$ THEN GOSUB $\$$ KEISUU 2 ELSE GOSUB $\star K E I S U U 1$

1730 DK $1=F * S *(3.14 * A 0) \wedge .5$

1740 IF DKI $>$ DKTH GOTO 1760

1750 NEXT J

1760 PRINT" 伝ぱ開始き裂長さ (AP) = ";AO:"(nn)"

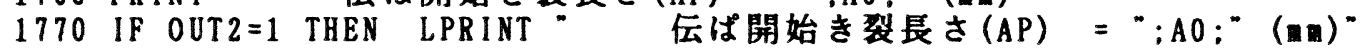

$1780 \quad \mathrm{~A} 1=\mathrm{AO}-.01$

$1790 \mathrm{NP}=0$

$1800 \quad A 1=A 1+.01$

$1810 \quad A 2=A 1+.01$

$1820 \mathrm{RO}=\mathrm{A} 1 / \mathrm{T}$

1830 IF RO> LIMIT THEN GOSUB *SUCES2 : END

$1840 \mathrm{R}=(\mathrm{A} 1+\mathrm{A} 2) /(2 * T)$

1850 IF TYPE $=2$ THEN GOSUB $*$ KEISUU2 ELSE GOSUB $*$ KEISUU 1

$1860 N 1=2 *\left(A 1^{\wedge}(1-(M / 2))-A 2^{\wedge}(1-(M / 2))\right) /(C *(M-2) *((1.77 * F * S) \wedge M))$

$1870 \mathrm{NP}=\mathrm{NP}+\mathrm{N} 1$

1880 GOTO 1800

1890 END

$1900 \cdot$ サブルーチン

$1910 *$ KEISUU 1

$1920 \mathrm{~F}=1.135-.3929 * U-.344 * U^{\wedge} 2+.2613 * U^{\wedge} 3+R *\left(-1.5184+.4178 * U+.7846 * U^{\wedge} 2-.6329 * U^{\wedge} 3\right)+$ $R * R *\left(4.3721-13.9152 * U+16.255 * U^{\wedge} 2-6.4894 * U^{\wedge} 3\right)+R * R * R *\left(-3.9502+12.5334 * U-14.6137 * U^{\wedge}\right.$ $\left.2+5.811 * U^{\wedge} 3\right)$

1930 RETURN

$1940 *$ KEISUU2

$1950 \mathrm{~F}=\left(1.122-.23 * U-.901 * U^{\wedge} 2+.949 * U^{\wedge} 3-.28 * U^{\wedge} 4\right) *\left(1 !+.157 * 2 * R-.634 * 4 * R^{\wedge} 2+4.59 * 8 * R^{\wedge}\right.$

$\left.3-6.628 * 16 * R^{\wedge} 4\right) *\left(1.121-1.199 * R+4.775 * R^{\wedge} 2-1.628 * R^{\wedge} 3-7.035 * R^{\wedge} 4+13.27 * R^{\wedge} 5\right) /(1.12-.2$

$\left.31 * R+10.55 * R^{\wedge} 2-21.72 * R^{\wedge} 3+30.39 * R^{\wedge} 4\right)$

1960 RETURN

$1970 \notin P R N 1$

1980 PRINT

1990 PRINT"**** 評価き裂長さの計算***”

2000 PRINT" 試䄼番号 =":TPNOS

2010 PRINT". ばね程 = “: STR1\$

2020 PRINT " ":STR2\$:" = "T:" (ma)"

2030 PRINT" 底力筑囲 $=" ; S: "\left(\mathrm{kgf} / \mathrm{m}{ }^{\wedge} 2\right)^{\prime}$

2040 PRINT - 残存寿命 $="$; N; $"(\text { cycles })^{\prime \prime}$

2050 RETURN

2060 \$SUCES 1

2070 PRINT" 評価を裂長さ $(\mathrm{AO})=" ; \mathrm{AO}: "(\mathrm{mn}) "$

2080 PRINT" 残存寿命 $(N)=" ; N ; "$ "伝ぱ成程の寿命 $(N P)=" ; N$

2090 IF OUT2 $=1$ THEN LPRINT" 評価き裂長さ $(\mathrm{AO})=$ " $\mathrm{AO}$;" (m)

2100 IF OUT2 $=1$ THEN LPRINT - 残存寿命 $(N)=" ; N ; "$ 伝ぱ迥程の寿命 (NP) =

; N

2110 RETURN

$2120 *$ SUCES 2

$2130 \mathrm{NI}=\mathrm{N}-\mathrm{NP}$

2140 PRINT" 残存寿命 $(N)=": N$

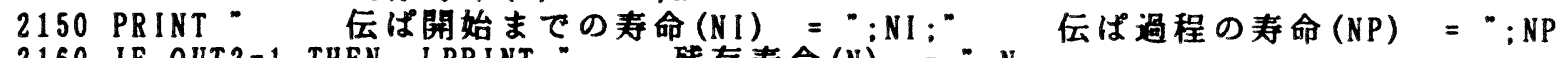

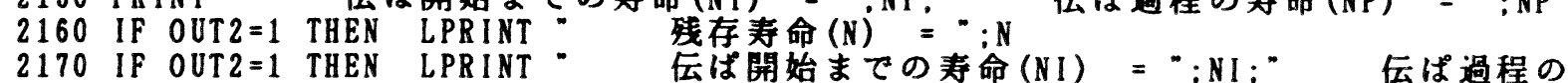
寿命 $((N P)=$; NP

2180 RETURN

2190 *LPRN 1

2200 LPRINT

2210 LPRINT

2220 LPRINT

2230 LPRINT

2240 LPRINT

2250 LPRINT

2260 LPRINT

2270 RETURN

評価き㛄長さの計算

試跧番号 = "; TPNOS

ばね程 =“:STR1\$

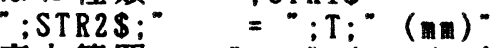

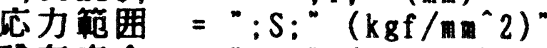

残存寿命 $=" ; N ; "(\text { cycles })^{\prime \prime}$ 